\title{
Design, Synthesis and Biological Evaluation of Indoline Derivatives as Multifunctional Agents for the Treatment of Ischemic Stroke
}

Shuaishuai Du (D1729511049@qq.com )

Anhui University of Chinese Medicine https://orcid.org/0000-0001-5545-9749

Fan Jin

Anhui University of Chinese Medicine

Jiaming Li

Anhui University of Chinese Medicine

Xiaodong Ma

Anhui University of Chinese Medicine

Hongwei Wang

Anhui University of Chinese Medicine

Shihu Qian

Anhui University of Chinese Medicine

\section{Research Article}

Keywords: Ischemic stroke, Indoline derivatives, Antioxidant, Anti-inflammatory, NMDA-GluN2B receptor, Neuroprotective.

Posted Date: December 16th, 2021

DOI: https://doi.org/10.21203/rs.3.rs-1144423/v1

License: (c) (i) This work is licensed under a Creative Commons Attribution 4.0 International License.

Read Full License

Version of Record: A version of this preprint was published at Medicinal Chemistry Research on April 13th, 2022. See the published version at https://doi.org/10.1007/s00044-022-02875-1. 


\section{Design, synthesis and biological evaluation of indoline derivatives as multifunctional agents for the treatment of ischemic stroke}

Shuaishuai $\mathrm{Du}^{1} \cdot$ Fan Jin ${ }^{1} \cdot$ Jiaming $\mathrm{Li}^{1,2} \cdot$ Xiaodong Ma ${ }^{1,2} \cdot$ Hongwei Wang ${ }^{1} \cdot$ Shihu Qian ${ }^{1}$

Shuaishuai $\mathrm{Du}^{1}$

1729511049@qq.com

Fan Jin ${ }^{1}$

2280925161@qq.com

$凶$ Jiaming $\mathrm{Li}^{1,2}$

lijiaming2017@sina.com

凶 Xiaodong $\mathrm{Ma}^{1,2}$

o-omaxiaodong@163.com

Hongwei Wang ${ }^{1}$

18119629721@163.com

Shihu Qian ${ }^{1}$

1306683313@qq.com

\footnotetext{
${ }^{1}$ School of Pharmacy, Anhui University of Chinese Medicine, Hefei 230031, China

${ }^{2}$ Department of Medicinal Chemistry, Anhui Academy of Chinese Medicine, Hefei 230031, China
} 
Abstract In this work, a series of indoline derivatives as multifunctional neuroprotective agents for battling ischemic stroke were designed, synthesized, and biologically evaluated. In antioxidant assay, all compounds showed significant protective effects against $\mathrm{H} 2 \mathrm{O} 2$-induced death of RAW 264.7 cells. In oxygen glucose deprivation/reperfusion (OGD/R)-induced neuronal damage, some compounds significantly elevated the cell survival rate. Among them, $7 \mathrm{i}, 7 \mathrm{j}$ and $7 \mathrm{r}$ exerted comparable neuroprotective effects to Ifenprodil, and exhibited binding affinity to N-methyl-D-aspartic acid receptors 2B (NMDA-GluN2B). At the concentrations of $0.1,1$ and $10 \mu \mathrm{M}, 7 \mathrm{i}, 7 \mathrm{j}$ and $7 \mathrm{r}$ dose-dependently lowered the LPS-induced secretion of inflammatory cytokines, including TNF- $\alpha$, IL-6 and NO, by BV-2 cells. Importantly, 7i and 7j can dramatically reduce the cerebral infarction rate and improve neurological deficit scores in middle cerebral artery occlusion (MCAO) rat model. As demonstrated by the above results, $7 \mathrm{i}$ and $7 \mathrm{j}$ are potential neuroprotective agents for the treatment of ischemic stroke.

\section{Graphical Abstract}

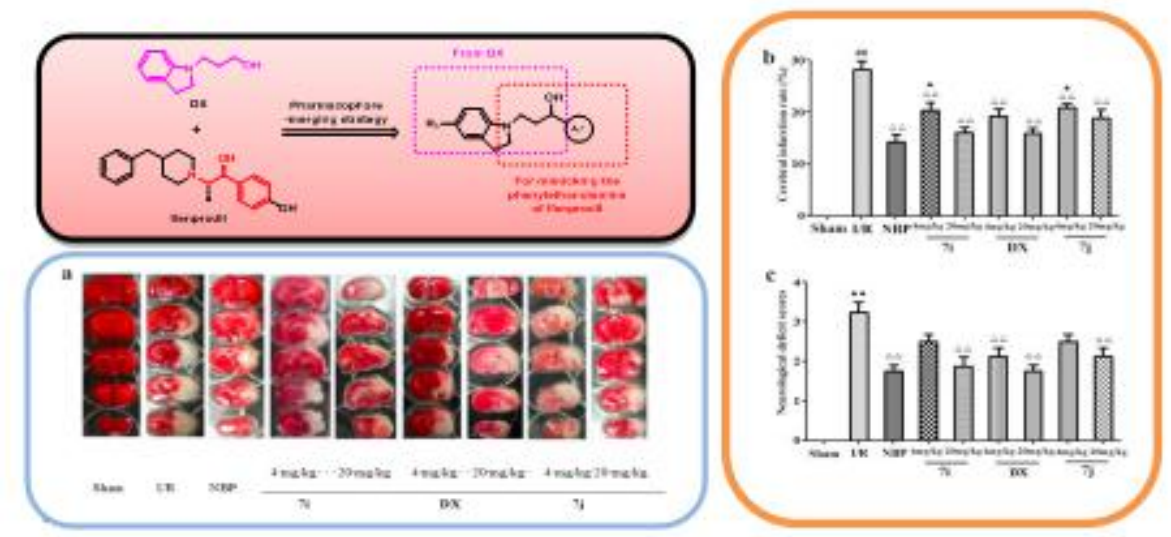

Keywords Ischemic stroke; Indoline derivatives; Antioxidant; Anti-inflammatory; NMDA-GluN2B receptor; Neuroprotective.

\section{Introduction}

Ischemic stroke (IS) refers to focal cerebral tissue necrosis or brain injury caused by the transient or permanent decrease of cerebral aortic blood flow, causing brain tissue ischemia and hypoxia.Cerebral ischemia triggers the pathological pathway of the ischemic cascade and eventually causes irreversible neuronal damage to the ischemic core within a few minutes after onset ${ }^{[1]}$. Ischemicstroke, has emerged as the major cause of human death and long-term disability worldwide ${ }^{[2-3]}$.In recent years, with the increase of social pressure and the aging of the population, the number of stroke diseases continues to increase and there is a trend of younger generation ${ }^{[4]}$.

At present, treatment of cerebral ischemic stroke mainly focuses on recovering cerebral circulation and protecting brain tissue, emphasizing the necessity of a combination of both thrombolytic drugs and neuroprotective drugs ${ }^{[5]}$.Although 
thrombolysis and thrombectomy are the main treatment strategies in the early stage of clinical ischemic stroke, due to the narrow treatment time window, the strategies are biased ${ }^{[6]}$. Other than vascular recanalization, the application of neuroprotective agents represents the most promising strategy for treating this disease ${ }^{[7]}$. It was found that the time window of thrombolytic therapy can be significantly prolonged by post-ischemic neuroprotective treatments. Therefore, the etiology and pathology of ischemic stroke should be simultaneously considered in order tofind suitable therapeutic drugs and explore potential therapeutic molecular targets for neuroprotective sdrug development ${ }^{[8]}$.

Mounting studies have revealed that ischemic stroke is initiated and promoted by a complex cascade of pathological events involving the release of numerous cytokines, and the activation of multiple signal transductions ${ }^{[9]}$. The main pathogenesis is associated with the intermediate blockage of the cerebral blood vessels, culminating in the severe lack of oxygen and energy, excessive release of excitatory amino acids, and inflow of a large amount of calcium ions ${ }^{[10]}$. Due to the hypoxia, a large number of active oxygen species are produced, thereby inducing cell damage, facilitating the peripheral leukocyte infiltration, activating endogenous microglia, and consequently mediating inflammation [11-12]. Furthermore, the cross-talk and interaction among these pathological processes initiates the neuronal apoptosis ${ }^{[13]}$. In light of the complex pathogenesis, the application of therapeutic agents with multi-faceted biological activities, including anti-inflammation, antioxidant, and glutamate receptor antagonism, is beneficial to improving the efficacy for treating ischemic stroke.

Recently, a class of indoline derivatives has been reported to display more significant antioxidant activity than corresponding indole derivatives (Fig 1). In vitro, they also exerted protective efficacy against reactive oxygen species (ROS)-inducedcytotoxicity. In addition, these compounds were capable to reduce the release of TNF- $\alpha$ and IL-6 from LPS-stimulated macrophages ${ }^{[14]}$.
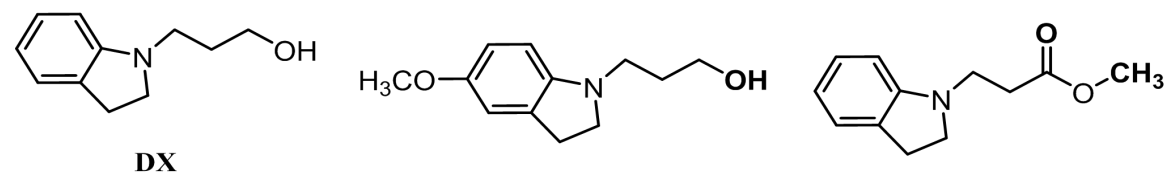

Fig 1 Indoline derivatives with anti-inflammatory and antioxidant activities

During cerebral ischemia, excessive stimulation of NMDA-GluN2B receptors caused by glutamate has long been thought to promote neuronal death ${ }^{[15-17]}$. Therefore, NMDA-GluN2B receptor antagonists have the potential to treat ischemic stroke. Classical selective GluN2B receptor inhibitors, including Ifenprodil (Fig 2), Eliprodil and Traxoprodil, can effectively inhibit glutamate-induced hippocampal neurotoxicity. However, the clinical investigation of Traxoprodil has been terminated due to cardiovascular toxicity [18-20]. These classic NMDA-GluN2B receptor antagonists are structurally characterized by of the phenylethanolamine scaffold and a hydrophobic group tethered to the 4-position of the 
piperidine ${ }^{[21]}$. As confirmed by the antagonist/receptor complex, the phenylethanolamine was vital for the binding affinity [22].

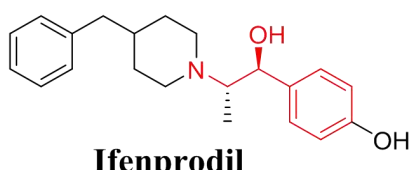

Ifenprodil

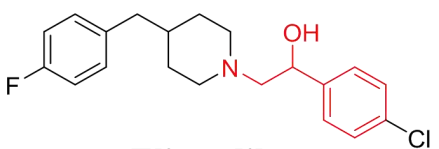

Eliprodil

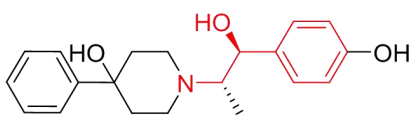

Traxoprodil

Fig 2 Classic antagonist of NMDA-GluN2B receptor

Considering the role of ROS, inflammation, and NMDA-GluN2B receptor in the pathology of ischemic stroke, indoline derivative DX, that exerts the anti-oxidative and anti-inflammatory activities, was structurally merged with Ifenprodil for achieving a multi-target intervention. Upon this strategy, a novel series of indoline derivatives, incorporating the structural features of both $\mathbf{D X}$ and Ifenprodil, were designed, synthesized, and biologically evaluated (Fig 3). Among them, $\mathbf{7 i}$ and $\mathbf{7} \mathbf{j}$ were screened as potential multi-functional neuroprotective agents for the treatment of ischemic stroke.
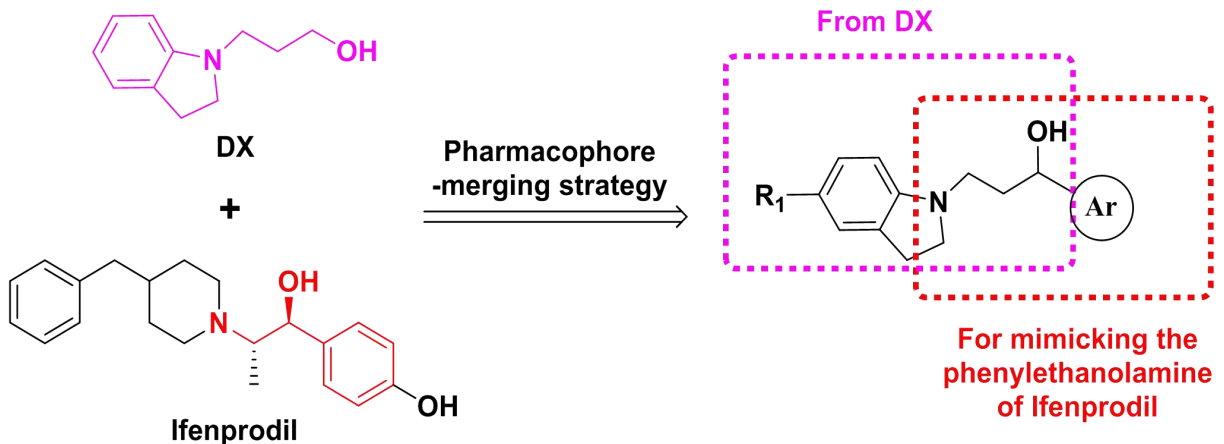

Fig 3 Design rationale of compounds

\section{Results and discussion}

\subsection{Chemistry}

The synthetic route for target compounds is displayed in Scheme 1. The commercially available substituted indoles were reduced by sodium cyanoborohydride to afford corresponding indolines. Meanwhile, Grignard reaction between aromatic aldehydes 3a-r and vinylmagnesium bromide furnished the secondary alcohol, which was coped with chromium trioxide to generate the $\alpha, \beta$-unsaturated ketones 5a-r. The following Michael addition with the indolines and the reduction of the carbonyl functionality led to the formation of 7a-r as the target compounds (Tab 1). 

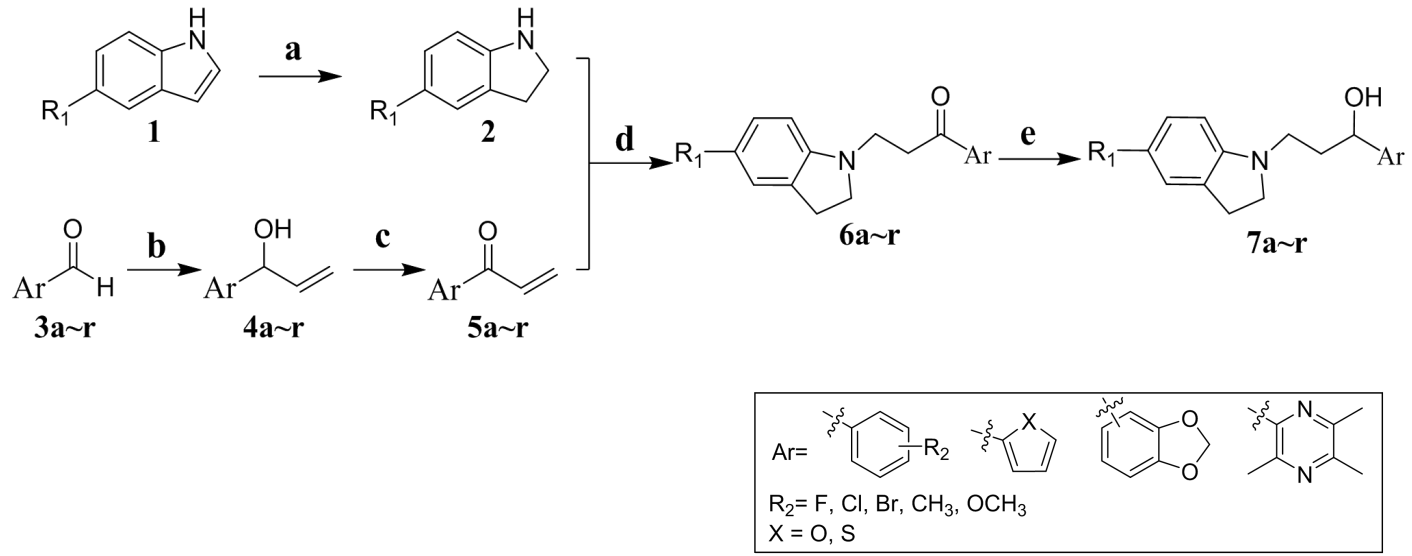

Reagents and conditions: (a) $\mathrm{NaBH}_{3} \mathrm{CN}$, AcOH, r.t.; (b) THF, Vinylmagnesium bromide, $0 \sim 25^{\circ} \mathrm{C}$; (c) $\mathrm{CrO}_{3} / \mathrm{H}_{2} \mathrm{SO}_{4}$, acetone, $0^{\circ} \mathrm{C}$ or $\mathrm{Active}$ $\mathrm{MnO}_{2}, \mathrm{C}_{2} \mathrm{H}_{5} \mathrm{OH}$, reflux; (d) $\mathrm{CH}_{3} \mathrm{CN}, 25^{\circ} \mathrm{C}$; (e) $\mathrm{NaBH}_{4}, \mathrm{CH}_{3} \mathrm{OH}, 0 \sim 25^{\circ} \mathrm{C}$.

Scheme 1 Synthetic pathways for compounds 7a-r

Tab 1 Biologically tested indoline derivatives

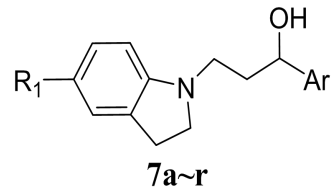<smiles>[R]c1ccc2c(c1)CCN2CCC(=O)[Al]</smiles>

6h, 6i, 61

\begin{tabular}{|c|c|c|c|c|c|c|c|c|}
\hline Cpd. & $\mathbf{R}_{1}$ & Ar & Cpd. & $\mathbf{R}_{1}$ & Ar & Cpd. & $\mathbf{R}_{1}$ & Ar \\
\hline $7 a$ & $\mathrm{OCH}_{3}$ & & $7 \mathrm{~h}$ & $\mathbf{H}$ & & 70 & $\mathbf{H}$ & \\
\hline $7 b$ & $\mathrm{OCH}_{3}$ & & $7 \mathbf{i}$ & $\mathbf{H}$ & & $7 p$ & H & \\
\hline $7 c$ & $\mathbf{H}$ & & $7 \mathbf{j}$ & H & & $7 q$ & H & \\
\hline $7 d$ & $\mathbf{H}$ & & $7 k$ & $\mathbf{H}$ & & $7 r$ & $\mathrm{OCH}_{3}$ & \\
\hline $7 e$ & $\mathrm{OCH}_{3}$ & & 71 & $\mathbf{H}$ & & 61 & $\mathbf{H}$ & \\
\hline $7 f$ & $\mathrm{OCH}_{3}$ & & $7 \mathrm{~m}$ & $\mathrm{OCH}_{3}$ & & $6 i$ & $\mathbf{H}$ & \\
\hline $7 g$ & $\mathrm{OCH}_{3}$ & & $7 n$ & $\mathbf{H}$ & & $6 h$ & $\mathbf{H}$ & \\
\hline
\end{tabular}




\subsection{Biological evaluation}

\subsubsection{Antioxidant Assays}

All the target compounds were evaluated for their protective effects against RAW 264.7 cell death induced by $\mathrm{H}_{2} \mathrm{O}_{2}$ in vitro. As demonstrated by the biological data in $\mathbf{T a b} \mathbf{2}$, all compounds exhibited significant cytoprotective activity against $\mathrm{H}_{2} \mathrm{O}_{2}$ induced oxidative damage compared with the model group. Among them, the antioxidant activity of compounds $\mathbf{7 a}, \mathbf{7 d}, \mathbf{7 f}, \mathbf{7 l}, \mathbf{7 q}$, and $\mathbf{7 i}$ is better than the lead compound ifenprodil. Unfortunately, the antioxidant activity of these synthesized compounds is poorer than the lead compound $\mathbf{D X}$ at a concentration of 1 100 nM. Exploring the anti-oxidation results of the compound in vitro, we found that regardless of whether $\mathbf{R}_{\mathbf{2}}$ is electron-withdrawing or electron-donating, when the substituents of $\mathbf{R}_{\mathbf{2}}$ are the same, the antioxidant activity of $\mathbf{R}_{\mathbf{1}}$ containing $\mathbf{H}$ is better than that of $\mathbf{R}_{\mathbf{1}}$ containing $\mathbf{O C H}_{3}$. Among these, these compounds with $\mathbf{4}-\mathbf{C H}_{\mathbf{3}}$ or $\mathbf{4 - O C H _ { 3 }}$ in $\mathbf{R}_{2}$, its antioxidant activity decreases more significantly. However, when the phenyl group contains two electron-donating substituents, it is beneficial to increase the antioxidant act vity. Chlorine-substituted compounds $\mathbf{7 d}, \mathbf{7 h}$ and $\mathbf{7 p}$ have better para-position antioxidant activity than meta-position and ortho-position. In addition, the antioxidant activity of chlorine substitution is better than that of bromine substitution. Analyzing the structure-activity relationship of $\mathbf{7 h}, \mathbf{7} \mathbf{j}, \mathbf{6 i}$, and $\mathbf{6 h}$, it is found that the activity of carbonyl groups is better than that of hydroxyl group. Overall, there is no order for magnitude difference in the antioxidant activity of these compounds compared with the lead compounds $\mathbf{D X}$ and ifenprodil.

Tab 2 Survival rate of RAW 264.7 cells in the presence of different compounds after $24 \mathrm{~h}$ incubation

\begin{tabular}{|c|c|c|c|c|c|}
\hline \multirow{2}{*}{ Cpd. } & \multirow{2}{*}{ Control } & \multirow{2}{*}{ Model } & \multicolumn{3}{|c|}{ Survival rate( $\%) \pm$ SD } \\
\hline & & & $1 \mathrm{nM}$ & $10 \mathrm{nM}$ & $100 \mathrm{nM}$ \\
\hline $7 \mathbf{a}$ & $100 \pm 2.71$ & $72.98 \pm 1.27$ & $83.99 \pm 4.40^{* * \# \#}$ & $87.97 \pm 3.56^{* * \#}$ & $91.30 \pm 3.47^{* *}$ \\
\hline $7 \mathbf{b}$ & $100 \pm 2.09$ & $72.88 \pm 1.40$ & $80.06 \pm 4.93^{* * \# \#}$ & $82.65 \pm 40^{* * \# \#}$ & $85.22 \pm 2.46^{* * \#}$ \\
\hline $7 c$ & $100 \pm 2.35$ & $73.72 \pm 1.59$ & $80.24 \pm 1.89^{* * \# \#}$ & $84.49 \pm 1.26^{* * \# \#}$ & $88.71 \pm 2.43^{* * \#}$ \\
\hline $7 d$ & $100 \pm 2.36$ & $73.77 \pm 2.76$ & $83.52 \pm 2.60^{* * \# \#}$ & $88.78 \pm 6.78^{* * \#}$ & $90.26 \pm 4.52^{* *}$ \\
\hline $7 e$ & $100 \pm 2.67$ & $72.87 \pm 0.73$ & $79.79 \pm 2.15^{* * \# \#}$ & $81.34 \pm 3.77^{* * \#}$ & $84.45 \pm 2.88^{* * \# \#}$ \\
\hline $7 f$ & $100 \pm 1.89$ & $74.13 \pm 2.75$ & $85.57 \pm 1.38^{* * \#}$ & $88.62 \pm 2.95^{* * \#}$ & $91.64 \pm 1.70^{* *}$ \\
\hline $7 g$ & $100 \pm 2.36$ & $72.90 \pm 1.95$ & $81.10 \pm 4.45^{* * \# \#}$ & $84.35 \pm 2.91^{* * \#}$ & $87.52 \pm 5.13^{* * \#}$ \\
\hline $7 \mathbf{h}$ & $100 \pm 3.21$ & $73.62 \pm 1.10$ & $82.72 \pm 1.54^{* * \# \#}$ & $85.27 \pm 1.84^{* * \#}$ & $87.57 \pm 3.43^{* * \#}$ \\
\hline $7 \mathbf{i}$ & $100 \pm 2.03$ & $72.56 \pm 1.85$ & $79.25 \pm 0.25^{* * \# \#}$ & $84.77 \pm 1.10^{* * \#}$ & $86.6 \pm 2.23^{* * \# \#}$ \\
\hline $7 \mathbf{j}$ & $100 \pm 1.60$ & $73.39 \pm 3.18$ & $85.13 \pm 2.80^{* * \#}$ & $88.56 \pm 2.86^{* * \#}$ & $90.02 \pm 1.06^{* *}$ \\
\hline $7 \mathbf{k}$ & $100 \pm 4.23$ & $73.35 \pm 2.24$ & $79.25 \pm 2.36^{* * \# \#}$ & $83.23 \pm 1.33^{* * \#}$ & $85.51 \pm 4.63^{* * \# \#}$ \\
\hline 71 & $100 \pm 2.77$ & $73.15 \pm 1.76$ & $83.29 \pm 0.47^{* * \#}$ & $88.08 \pm 3.75^{* * \#}$ & $90.97 \pm 1.86^{* *}$ \\
\hline $7 \mathrm{~m}$ & $100 \pm 1.73$ & $73.04 \pm 1.24$ & $81.74 \pm 3.76^{* * \# \#}$ & $84.32 \pm 2.27^{* * \#}$ & $88.42 \pm 2.84^{* * \#}$ \\
\hline $7 n$ & $100 \pm 2.89$ & $73.00 \pm 1.27$ & $83.33 \pm 2.88^{* * \# \#}$ & $85.64 \pm 2.24^{* * \#}$ & $86.37 \pm 2.26^{* * \#}$ \\
\hline 70 & $100 \pm 1.77$ & $73.45 \pm 2.21$ & $80.20 \pm 1.10^{* * \# \#}$ & $82.55 \pm 0.71^{* * \#}$ & $84.97 \pm 3.95^{* * \# \#}$ \\
\hline $7 p$ & $100 \pm 1.84$ & $72.33 \pm 1.60$ & $79.31 \pm 3.08^{* * \# \#}$ & $81.16 \pm 2.31^{* * \#}$ & $82.74 \pm 3.42^{* * \# \#}$ \\
\hline $7 q$ & $100 \pm 1.14$ & $72.39 \pm 1.45$ & $89.73 \pm 2.36^{* *}$ & $90.55 \pm 3.11^{* *}$ & $92.45 \pm 1.46^{* *}$ \\
\hline $7 r$ & $100 \pm 2.31$ & $72.37 \pm 0.95$ & $85.30 \pm 3.49^{* *}$ & $88.78 \pm 1.70^{* *}$ & $90.02 \pm 3.45^{* *}$ \\
\hline 61 & $100 \pm 2.88$ & $72.79 \pm 0.63$ & $78.44 \pm 3.25^{* \#}$ & $80.85 \pm 2.59^{* * \#}$ & $83.43 \pm 2.91^{* * \# \#}$ \\
\hline $6 \mathbf{i}$ & $100 \pm 2.31$ & $73.24 \pm 1.35$ & $85.24 \pm 2.52^{* *}$ & $89.70 \pm 6.02^{* *}$ & $91.51 \pm 2.21^{* *}$ \\
\hline $6 h$ & $100 \pm 0.37$ & $72.80 \pm 0.68$ & $84.61 \pm 2.48^{* * \#}$ & $86.23 \pm 5.90^{* * \#}$ & $89.13 \pm 1.39^{* * \#}$ \\
\hline DX & $100 \pm 0.45$ & $73.80 \pm 2.75$ & $90.02 \pm 6.63^{* *}$ & $92.57 \pm 2.44^{* *}$ & $94.78 \pm 4.23^{* *}$ \\
\hline ifenprodil & $100 \pm 3.11$ & $71.23 \pm 3.44$ & $81.53 \pm 2.55^{* *}$ & $86.96 \pm 0.60^{* *}$ & $90.24 \pm 2.64^{* *}$ \\
\hline
\end{tabular}


Effects of all target compounds on RAW 264.7 cell on exposed to $\mathrm{H}_{2} \mathrm{O} 2$. RAW 264.7 cells were treated with $\mathrm{H}_{2} \mathrm{O}_{2}(100 \mu \mathrm{M})$, and then the cell viability was detected by MTT method. Survival rate(\%) $=($ OD value of experimental group/OD value of control group $) \times 100 \%$. All date were shown as the mean $\pm \mathrm{SD}(\mathrm{n}=5$ per group) of triplicate in three independent experiments,

\subsubsection{Neuroprotection against injury by $\mathbf{O G D} / \mathrm{R}$.}

The neuronal damage induced by $\mathrm{OGD} / \mathrm{R}$ is a frequently applied model for the in vitro evaluation of the protective effects against cerebral ischemia-reperfusion (I/R) injury. As shown in Fig 4, in comparison with the control groups, a sharp decrease in the cell survival rate was observed as for the model groups treated by OGD/R. On the contrary, the survival rate of neuronal cells is in a dose-dependent manner upon the pretreatment with $\mathbf{7 a}, \mathbf{7} \mathbf{i}, \mathbf{7} \mathbf{j}, 7 \mathbf{k}, 7 \mathbf{m}, \mathbf{7 q}, \mathbf{7 r}$ and Ifenprodil. Among the tested target compounds, $7 \mathbf{i}, \mathbf{7} \mathbf{j}$ and $\mathbf{7 r}$ exhibited better protective effects compared with other compounds. Hence, they were selected for further functional investigation.

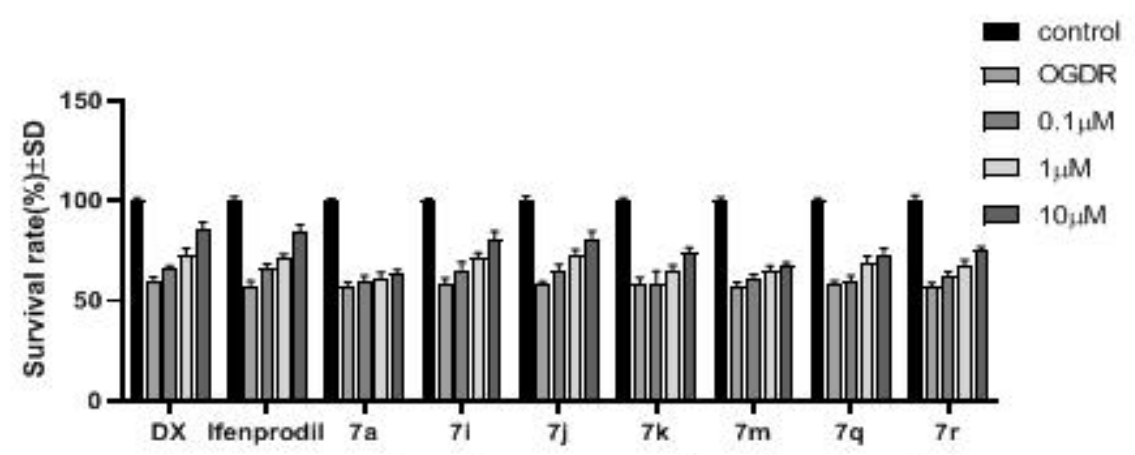

Fig 4 Neuroprotection of some compounds on injury by OGD/R

Effects of some compounds on neuronal cultures exposed to OGD. Survival rate(\%) $=(\mathrm{OD}$ value of experimental group/OD value of control group) $\times 100 \%$. All data are expressed in mean $\pm \mathrm{SD} .{ }^{*} p<0.05$, ${ }^{* *} p<0.01$ vs the OGD/R group, repeat 5 times for each concentration.

\subsubsection{Competitive binding of $7 \mathbf{i}, 7 \mathbf{j}$ and $7 \mathbf{r}$ to GluN2B receptor.}

The over activation of GluN2B receptor, a subtype of NMDA receptor, is involved in the occurrence and development of ischemic stroke. Therefore, we tested the competitive binding affinity with $\mathbf{7 i}, \mathbf{7} \mathbf{j}$ and $\mathbf{7 r}$ to the GluN2B receptor with the attempt to explore the possible mechanisms of neuroprotection. As reported in Table 3, a preliminary binding assay using $[3 \mathrm{H}]$ ifenprodil has been carried out to measure the percentage of inhibition atfixed dose of $5 \mathrm{nM}, 20$ $\mathrm{nM}, 80 \mathrm{nM}$ concentration. The ifenprodil and as reference compounds to compare the binding affinity potencies of the new indoline derivatives. The experimental results show that the newly synthesized compound has higher activity than ifendil, and compounds $7 \mathrm{i}, 7 \mathrm{j}$, and $7 \mathrm{r}$ at a concentration of $80 \mathrm{~nm}$ show higher affinity than ifendil at a concentration of $100 \mathrm{mn}$. The electron withdrawing group and the electron donating group have no obvious effect on the activity, but the five-membered ring furan significantly increases the affinity. These data indicate that the larger Ar group has a negative effect on the binding affinity. 
Tab 3 GluN2B/NMDA binding affinities of indoline derivatives

\begin{tabular}{ccc}
\hline Compd. & concentration & Inhibition (\%) $^{\mathbf{a})}$ \\
\hline $\mathbf{7 i}$ & $5 \mathrm{nM}$ & $74.88 \pm 3.40$ \\
& $20 \mathrm{nM}$ & $76.53 \pm 4.04$ \\
& $80 \mathrm{nM}$ & $80.75 \pm 5.44$ \\
$7 \mathbf{j}$ & $5 \mathrm{nM}$ & $81.36 \pm 5.74$ \\
& $20 \mathrm{nM}$ & $85.79 \pm 0.99$ \\
& $80 \mathrm{nM}$ & $86.57 \pm 1.66$ \\
$7 \mathbf{r}$ & $5 \mathrm{nM}$ & $69.82 \pm 5.68$ \\
& $20 \mathrm{nM}$ & $77.08 \pm 5.06$ \\
ifenprodil & $80 \mathrm{nM}$ & $80.33 \pm 4.98$ \\
\hline
\end{tabular}

a) Displacement of $[3 \mathrm{H}]$ ifenprodil, three concentrations $(5 \mathrm{nM}, 20 \mathrm{nM}, 80 \mathrm{nM}$, in duplicate $)$ of test compounds were used in displacement assay, repeat three times for each concentration

b) Data from reference ${ }^{[23]}$

\subsubsection{Potency to inhibit the secretion of TNF- $\alpha$ 、IL-6 and NO by LPS induced BV-2 cells}

Considering the inflammatory response is a major pathological event in the occurrence and development of ischemic stroke, we then investigated the effect of $\mathbf{7 i}, \mathbf{7} \mathbf{j}$ and $\mathbf{7 r}$ on the release of inflammatory cytokines. As shown in Fig $\mathbf{5}$, when BV-2 cells were pretreated with the tested compound, the release content of TNF- $\alpha$, IL-6 and NO was lowered in a dose-dependent manner. Among them, compound $\mathbf{7} \mathbf{i}$ showed the same inhibitory activity as the lead compound $\mathbf{D X}$. 

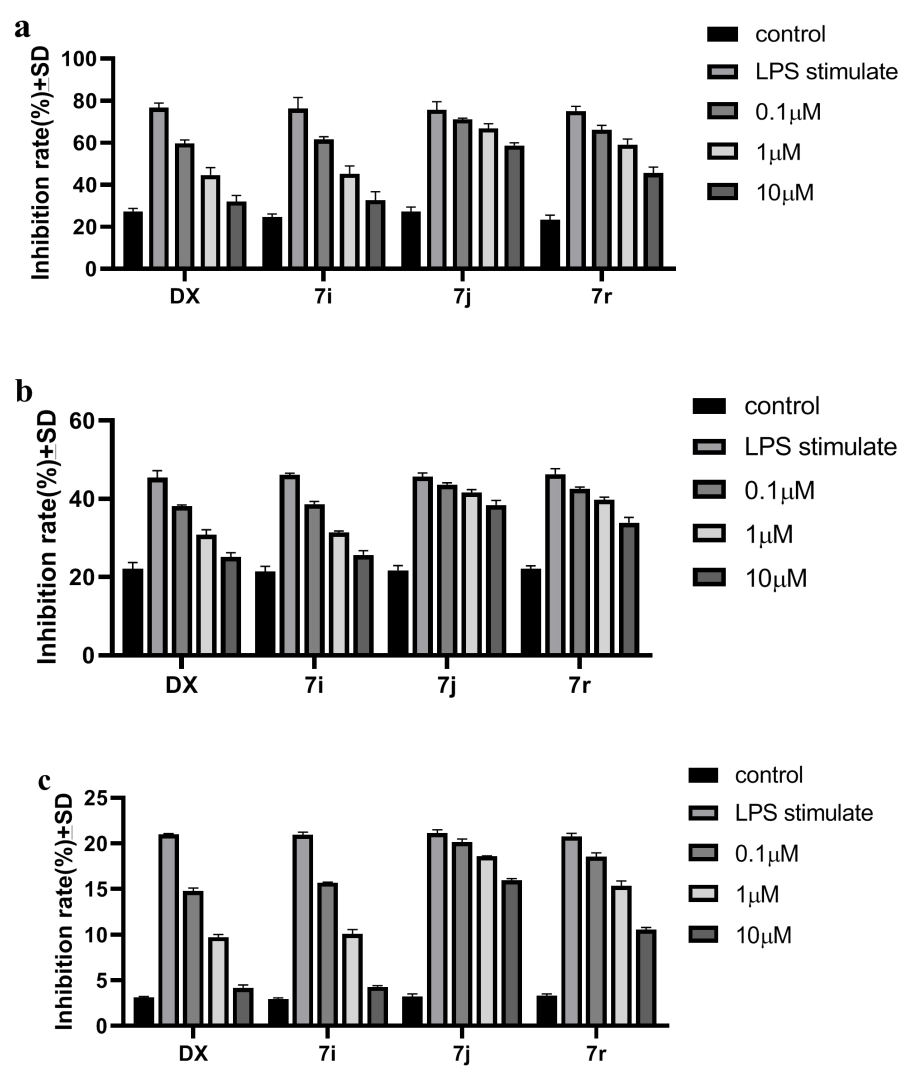

Fig 5 Effects of compounds on TNF- $\alpha(\mathbf{a})$, IL-6(b), NO(c) in LPS-stimulated BV2 cells. Inhibition rate(\%) $=(1-($ value of experimental group value of control group)/(value of LPS group - value of control group) $) \times 100 \%$. Date are shown as the mean \pm SD of three independent experiments $(n=3)$ run in triplicate

\subsubsection{Efficacy of compounds $7 \mathrm{i}$ and $7 \mathbf{j}$ on a middle cerebral artery occlusion (MCAO) rat model}

To assess the in vivo therapeutic efficacy of compound $\mathbf{7 i}$ and $\mathbf{7} \mathbf{j}$, a transient focal MCAO rat model was employed to simulate the temporary regional ischemia. In this experiment, infarct volume, neurological deficiency and water maze experiment were used to systematically investigate the process of the MCAO in the rat model. As shown in Fig 6, a significant neurological deficit score and extensive infarct volume were all presented by 90 min MCAO-induced ischemia and $24 \mathrm{~h} \mathrm{I} / \mathrm{R}$ as compared with the sham operated group. Pretreatment with n-butylphthalide (NBP) (20 mg/kg), 7i (20 $\mathrm{mg} / \mathrm{kg}), 7 \mathbf{j}(20 \mathrm{mg} / \mathrm{kg})$, ifenprodil $(20 \mathrm{mg} / \mathrm{kg})$ and $\mathbf{D X}(4 \mathrm{mg} / \mathrm{kg}$ and $20 \mathrm{mg} / \mathrm{kg})$ markedly ameliorated this increment symptom and improved the neurological score as compared with the model group $(p<0.01)$. Furthermore, NBP and $7 \mathbf{i}, 7 \mathbf{j}$, ifenprodi, DX at each dosage can significantly reduce the cerebral infarction rate after MCAO $(p<0.01, p<0.05)$, and the efficacy of $7 \mathbf{i}$ is slightly better than the $\mathbf{7} \mathbf{j}$ at a dose of $20 \mathrm{mg} / \mathrm{kg}$, and is better than the ifenprodi at a dose of $20 \mathrm{mg} / \mathrm{kg}$. 


\section{a}
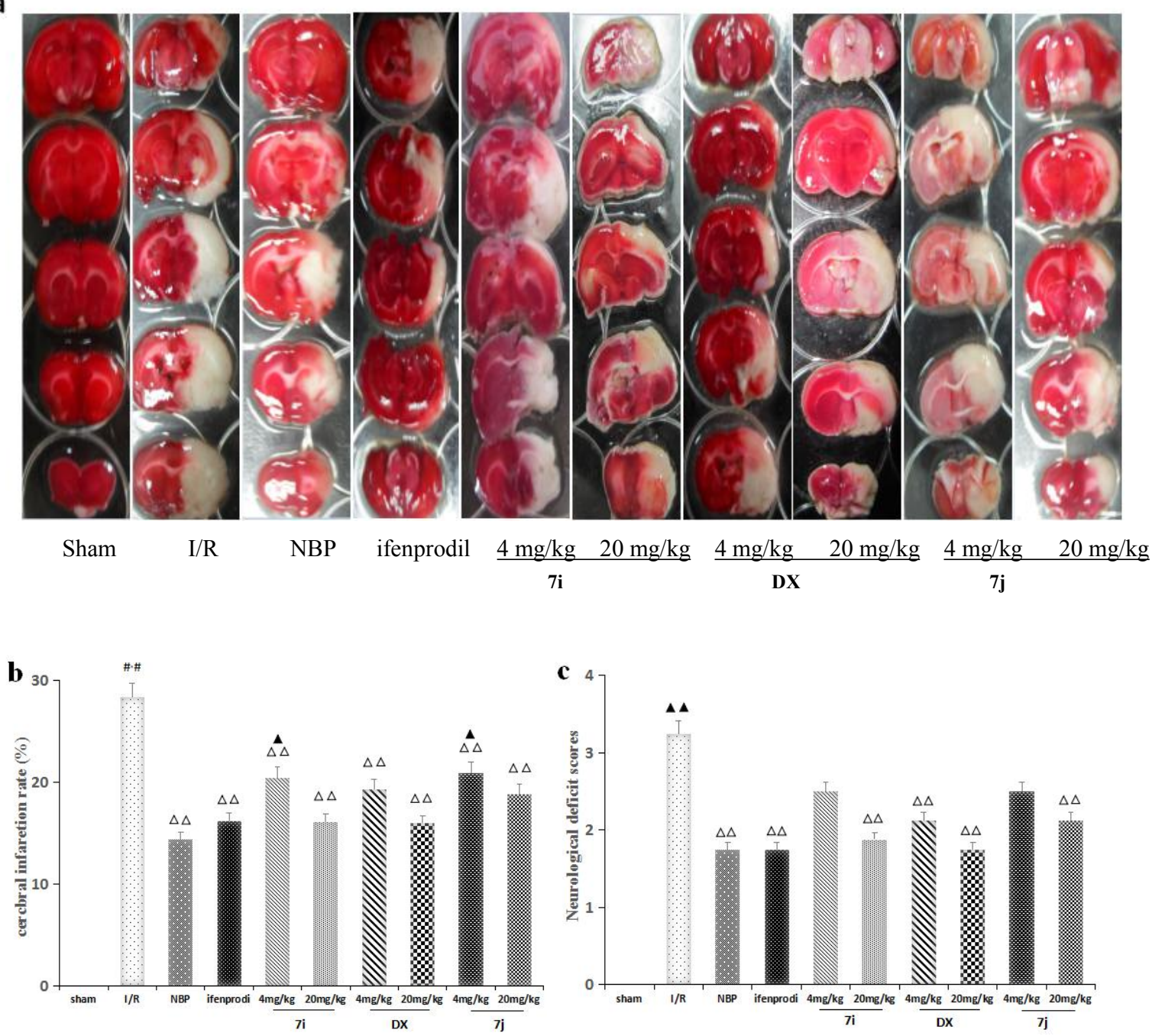

Fig 6 The neuroprotective effect of compound 7i, 7j, ifenprodi and $\mathbf{D X}$ were evaluated $24 \mathrm{~h}$ after cerebral ischemia and reperfusion in rats. a Representatives of TTC-stained brain slices. The white region shows the infarct size, while the red region shows the viable tissue. $\mathbf{b}$ Cerebral infarction rate(\%). c Neurological deficit scores. All data are expressed as mean $\pm \mathrm{SD}$ (n=8 per group). ${ }^{\#} P<0.05$, ${ }^{\#} P<0.01$ vs the sham group; ${ }^{\Delta} P<0.05,{ }^{\triangle} \Delta P<0.01$ vs the I/R group; ${ }^{\Delta} P<0.05, \quad \Delta \wedge<0.01$ vs positive group, respectively

\subsubsection{Morris water maze experiment of compound $7 \mathbf{i}, 7 \mathbf{j}$ and $D X$}

Furthermore, the Morris watered maze experiment, reflecting the learning and memory ability of experimental animals, was performed to evaluate the neuroprotective effect of the compound. As illustrated in Tab 4, the I/R (ischemiareperfusion) group had significant changes in the latency period and the times they crossed the platform $(P<0.01)$ compared with the sham group. Upon the treatment for 3 days, the NBP group, compound $7 \mathbf{i}$ (20 mg/kg), compound 7j and DX $(20 \mathrm{mg} / \mathrm{kg})$ can significantly improve the latency crossing the water maze and the times of crossing platforms $(P<0.01, P<0.05)$ at the dosage of $20 \mathrm{mg} / \mathrm{kg}$ compared with the $\mathrm{I} / \mathrm{R}$ group. There was no significant difference in NBP, 7i, 7j and DX-treated groups at the same dosage. 
Tab 4 Effect of morris water maze on focal cerebral ischemia induced by MCAO reperfusion in rats (Mean $\pm S D, n=8)$

\begin{tabular}{cccc}
\hline Grouping & dose $(\mathrm{mg} / \mathrm{kg})$ & incubation period $(\mathrm{s})$ & $\begin{array}{c}\text { Times of crossing } \\
\text { platform }\end{array}$ \\
\hline Sham & - & $7.5 \pm 2.3$ & $12.9 \pm 3.2$ \\
I/R & - & $32.3 \pm 7.1^{\# \#}$ & $3.9 \pm 2.0^{\text {\#\# }}$ \\
NBP & 20 & $24.8 \pm 3.8^{\triangle}$ & $8.1 \pm 1.8^{\triangle \triangle}$ \\
$7 \mathbf{i}$ & 4 & $27.8 \pm 7.7$ & $6.3 \pm 2.5$ \\
& 20 & $24.9 \pm 5.7^{\triangle}$ & $8.5 \pm 2.1^{\triangle \triangle}$ \\
DX & 4 & $27.4 \pm 6.0$ & $6.9 \pm 2.0$ \\
& 20 & $25.2 \pm 5.2^{\triangle}$ & $8.4 \pm 1.8^{\triangle \triangle}$ \\
$7 \mathbf{j}$ & 4 & $31.4 \pm 7.1$ & $6.1 \pm 1.9$ \\
& 20 & $27.6 \pm 6.7$ & $7.5 \pm 2.4^{\triangle}$ \\
\hline
\end{tabular}

All data are expressed as mean $\pm \mathrm{SD}$ (n=8 per group). ${ }^{\#} P<0.05,{ }^{\#} P<0.01$ vs the sham group; ${ }^{\triangle} P<0.05,{ }^{\triangle} P<0.01 \mathrm{vs}$ the I/R group; ${ }^{\Delta} P<0.05$,

$\triangle \triangle P<0.01$ vs positive group

\section{Conclusions}

In view of the complex pathology of ischemic stroke, a series of indoline derivatives with novel structures have been designed and synthesized. As a consequence of the successive biological screening, 7i and 7j were identified as potential neuroprotective agents for the treatment of ischemic stroke. In vitro, they displayed attractive protective activity against $\mathrm{H}_{2} \mathrm{O}_{2}$-induced cell death in RAW 264.7 cells, as well as comparable neuroprotective effects to Ifenprodil against OGD/R-induced neuronal damage. Moreover, both compounds exerted binding affinity to NMDA-GluN2B, and were capable of lowering the LPS-induced secretion of inflammatory cytokines in a dose-dependent manner. In vivo, 7i and 7j can significantly reduce the cerebral infarction rate and improve neurological deficit scores in $\mathrm{MCAO}$ rat model. In summary, compound $\mathbf{7} \mathbf{i}$ and $\mathbf{7} \mathbf{j}$ are potential neuroprotective agents for the treatment of ischemic stroke.

\section{Experimental}

\subsection{Chemistry}

The reagents and solvents for reaction were purchased from common commercial suppliers or purified by standard techniques. All chemical reactions were tested by TLC (using thin layer board with $254 \mathrm{~nm}$ fluorescent indicator). ${ }^{1} \mathrm{H}$ NMR spectra were recorded on a Bruker $400 \mathrm{MHz}$ spectrometer, and ${ }^{13} \mathrm{C}$ NMR spectra were recorded at $101 \mathrm{MHz}$. Chemical shifts were expressed in parts per million using tetramethylsilane as an internal reference and DMSO- $d_{6}$ as the solvent. ESI-MS spectra data were measured with a Hewlett-Packard 1100 LC/MSD spectrometer. HPLC was performed using a Shimadzu Essentia LC-16 system with UV detection at 254 nm. Compounds were eluted with a binary solvent system containing $\mathrm{A}$ and $\mathrm{B}$ [A: $\mathrm{CH}_{3} \mathrm{CN}$; $\mathrm{B}$ : $\mathrm{H}_{2} \mathrm{O}$ with $0.05 \%$ phosphoric acid $(\mathrm{W} / \mathrm{V})]$ at the flow rate of $0.8 \mathrm{~mL} / \mathrm{min}$. Analytical purity of the target compounds (all over $95 \%$ ) was 
presented in the supplementary material.

\subsubsection{General method for preparation of compounds 7a-7r.}

Compound 1 (13.3 mmol) was dissolved in $\mathrm{AcOH}(20 \mathrm{~mL}), \mathrm{NaBH}_{3} \mathrm{CN}(15.9 \mathrm{mmol})$ was added in portions, and the reaction mixture was stirred at $25^{\circ} \mathrm{C}$ for $1 \mathrm{~h}$. The reaction mixture was alkalized with $20 \% \mathrm{NaOH}$ to $\mathrm{pH}=9 \sim 10$. The solution was poured into the $100 \mathrm{~mL}$ water and extracted with EtOAc $(50 \mathrm{~mL} \times 3)$. The organic layers were pooled and washed with saturated $\mathrm{NaCl}$ and dried over $\mathrm{Na}_{2} \mathrm{SO}_{4}$. After concentration, the crude product was purified using column chromatography (EtOAc: $\mathrm{PE}=10: 1$ ) to afford Compound 2, yield $91 \sim 95 \%$.

A solution of Vinylmagnesium bromide $(32.0 \mathrm{mmol})$ in THF $(32 \mathrm{~mL})$ was added dropwise into a solution of $\mathbf{3 a}-\mathbf{3 r}$ $(16 \mathrm{mmol})$ in THF $(5 \mathrm{~mL})$ at $0^{\circ} \mathrm{C}$ under $\mathrm{N}_{2}$ (with stirring). After ending to drop, the reaction mixture was stirred at room temperature for $3 \mathrm{~h}$. The reaction mixture was poured slowly into the solution of saturated $\mathrm{NH}_{4} \mathrm{Cl}(250 \mathrm{~mL})$ and extracted with EtOAc $(60 \mathrm{~mL} \times 3)$. The organic layers were pooled and washed with saturated $\mathrm{NaCl}$ and dried over $\mathrm{Na}_{2} \mathrm{SO}_{4}$. $\mathrm{The}$ organic layer was filtered and concentrated under reduced pressure to give target compounds $\mathbf{4 a - 4 r}$, yield $20 \sim 97 \%$.

Jones reagent $(15 \mathrm{~mL})$ was added drop-wise into a solution of $\mathbf{4 a} \sim \mathbf{4 r}(15 \mathrm{mmol})$ in acetone $(20 \mathrm{~mL})$ at $0^{\circ} \mathrm{C}$. Upon completing the addition, the reaction was stirred at ice bath for $2 \mathrm{~h}$. The reaction mixture was poured into isopropanol (20 $\mathrm{mL})$ and suction. Then the filtrate was diluted with wate $(150 \mathrm{~mL})$ and extracted with EtOAc $(50 \mathrm{~mL} \times 3)$. The organic phase was separated and concentrated under reduced pressure to afford oil. The crude product was purified by column chromatography (PE: EtOAc=80: 1) to give 5a $\sim \mathbf{5 r}$, yield $50 \sim 70 \%$.

Compound $2(4.7 \mathrm{mmol})$ was added dropwise to a solution of $\mathbf{5 a} \sim \mathbf{5 r}(4.8 \mathrm{mmol})$ in $\mathrm{CH}_{3} \mathrm{CN}(10 \mathrm{~mL})$ and was stirred for $1 \mathrm{~h}$, keeping the reaction between $20 \sim 25^{\circ} \mathrm{C}$. After the reaction solution was concentrated under reduced pressure, the residue was purified by column chromatography (PE: EtOAc=80: 1) to give $6 \mathbf{a} \sim \mathbf{6 r}$, yield $80 \sim 90 \%$.

$\mathrm{NaBH}_{4}(4.2 \mathrm{mmol})$ was added into a solution of $6 \mathbf{a} \sim 6 \mathbf{r}(3.5 \mathrm{mmol})$ in $\mathrm{CH}_{3} \mathrm{OH}(15 \mathrm{~mL})$ in portions at $0^{\circ} \mathrm{C}$ and then the reaction mixture was stirred at room temperature for another $1 \mathrm{~h}$. The reaction solution pour into water $(120 \mathrm{~mL})$ and extracted with EtOAc $(50 \mathrm{~mL} \times 3)$. The combined organic layers were washed with water and dried over $\mathrm{Na}_{2} \mathrm{SO}_{4} . \mathrm{After}$ the organic was filtrated, the filtrate was concentrated to afford $\mathbf{7 a} \sim 7 \mathbf{r}$, yield $90 \sim 95 \%$.

\subsubsection{Characterization of target compounds.}

1-(4-fluorophenyl)-3-(5-methoxyindolin-1-yl)propan-1-ol (7a): White solid. 46\% yield. m.p. 75.4-76.3 ${ }^{\circ} \mathrm{C} .{ }^{1} \mathrm{H}$ NMR (400 MHz, DMSO-d $\left.d_{6}\right) \delta: 7.38(\mathrm{t}, J=6.2 \mathrm{~Hz}, 2 \mathrm{H}), 7.14(\mathrm{t}, J=8.6 \mathrm{~Hz}, 2 \mathrm{H}), 6.70(\mathrm{~s}, 1 \mathrm{H}), 6.57(\mathrm{~d}, J=7.9 \mathrm{~Hz}, 1 \mathrm{H})$, $6.33(\mathrm{~d}, J=8.3 \mathrm{~Hz}, 1 \mathrm{H}), 5.32(\mathrm{~d}, J=4.1 \mathrm{~Hz}, 1 \mathrm{H}), 4.69-4.65(\mathrm{~m}, 1 \mathrm{H}), 3.63(\mathrm{~s}, 3 \mathrm{H}), 3.19(\mathrm{dd}, J=13.8,7.9 \mathrm{~Hz}, 2 \mathrm{H}), 3.00$ $(\mathrm{t}, J=7.9 \mathrm{~Hz}, 2 \mathrm{H}), 2.82(\mathrm{t}, J=7.8 \mathrm{~Hz}, 2 \mathrm{H}), 1.81(\mathrm{dd}, J=6.4 \mathrm{~Hz}, 2 \mathrm{H}) .{ }^{13} \mathrm{C}$ NMR $\left(100 \mathrm{MHz}, \mathrm{DMSO}-d_{6}\right) \delta: 161.54\left(J_{\mathrm{C}-\mathrm{F}}=\right.$ $240.4 \mathrm{~Hz}), 152.68,147.26,142.83\left(J_{\mathrm{C}-\mathrm{F}}=2.8 \mathrm{~Hz}\right), 131.71,128.05\left(J_{\mathrm{C}-\mathrm{F}}=7.9 \mathrm{~Hz}, 2 \mathrm{C}\right), 115.13\left(J_{\mathrm{C}-\mathrm{F}}=20.8 \mathrm{~Hz}, 2 \mathrm{C}\right), 112.08$, 112.04, 107.79, 70.23, 55.95, 53.75, 47.16, 37.07, 28.85. HRMS Calculated for $\mathrm{C}_{18} \mathrm{H}_{20} \mathrm{FNO}_{2}[\mathrm{M}+\mathrm{H}]^{+} 302.1556$, found 302.1539. HPLC: $t_{R}=9.21 \mathrm{~min}$, Agilent TC-C18(2) $250 \times 4.6 \mathrm{~mm} 5 \mu \mathrm{m}, 40{ }^{\circ} \mathrm{C}$, eluent A- $60 \%$, eluent B- $40 \%$. 
1-(4-chlorophenyl)-3-(5-methoxyindolin-1-yl)propan-1-ol(7b): White solid. 45\% yield. m.p. $99.5-101.4^{\circ} \mathrm{C} .{ }^{1} \mathrm{H}$ NMR (400 MHz, DMSO-d 6 ) $\delta: 7.38(\mathrm{~s}, 4 \mathrm{H}), 6.70(\mathrm{~d}, J=1.9 \mathrm{~Hz}, 1 \mathrm{H}), 6.58-6.56(\mathrm{dd}, J=8.4,2.3 \mathrm{~Hz}, 1 \mathrm{H}), 6.34(\mathrm{~d}, J=$ $8.4 \mathrm{~Hz}, 1 \mathrm{H}), 5.38(\mathrm{~d}, J=4.6 \mathrm{~Hz}, 1 \mathrm{H}), 4.69-4.65(\mathrm{~m}, 1 \mathrm{H}), 3.63(\mathrm{~s}, 3 \mathrm{H}), 3.24-3.13(\mathrm{~m}, 2 \mathrm{H}), 3.07-2.93(\mathrm{~m}, 2 \mathrm{H}), 2.82(\mathrm{t}$, $J=8.1 \mathrm{~Hz}, 2 \mathrm{H}), 1.83-1.78(\mathrm{~m}, 2 \mathrm{H}) .{ }^{13} \mathrm{C}$ NMR (100 MHz, DMSO-d6) $\delta: 152.69,147.24,145.70,131.71,131.56$, 128.44(2C), 128.07(2C), 112.06, 112.04, 107.81, 70.16, 55.94, 53.75, 47.11, 36.96, 28.85. HRMS Calculated for $\mathrm{C}_{18} \mathrm{H}_{20} \mathrm{ClNO}_{2}[\mathrm{M}+\mathrm{H}]^{+}$318.1261, found 318.1258. HPLC: $\mathrm{t}_{\mathrm{R}}=11.95 \mathrm{~min}$, Agilent TC-C18(2) $250 \times 4.6 \mathrm{~mm} 5 \mu \mathrm{m}, 40{ }^{\circ} \mathrm{C}$, eluent A-60\%, eluent B-40\%.

1-(4-bromophenyl)-3-(indolin-1-yl)propan-1-ol(7c): White solid. $47 \%$ yield. m.p. $56.6-58.4{ }^{\circ} \mathrm{C} .{ }^{1} \mathrm{H}$ NMR $(400$ MHz, DMSO-d $\left.d_{6}\right) \delta: 7.51(\mathrm{~d}, J=8.3 \mathrm{~Hz}, 2 \mathrm{H}), 7.32(\mathrm{~d}, J=8.3 \mathrm{~Hz}, 2 \mathrm{H}), 7.00(\mathrm{~d}, J=7.1 \mathrm{~Hz}, 1 \mathrm{H}), 6.96(\mathrm{t}, J=7.7 \mathrm{~Hz}, 1 \mathrm{H})$, $6.54(\mathrm{t}, J=7.3 \mathrm{~Hz}, 1 \mathrm{H}), 6.40(\mathrm{~d}, J=7.8 \mathrm{~Hz}, 1 \mathrm{H}), 5.39$ (d, $J=4.6 \mathrm{~Hz}, 1 \mathrm{H}), 4.67-4.62(\mathrm{~m}, 1 \mathrm{H}), 3.30-3.21(\mathrm{~m}, 2 \mathrm{H}), 3.14$ - $3.02(\mathrm{~m}, 2 \mathrm{H}), 2.85(\mathrm{t}, J=8.3 \mathrm{~Hz}, 2 \mathrm{H}), 1.84-1.79(\mathrm{~m}, 2 \mathrm{H}) .{ }^{13} \mathrm{C}$ NMR (100 MHz, DMSO-d 6 ) $\delta: 152.86,146.09$, 131.35(2C), 130.10, 128.46(2C), 127.54, 124.56, 120.05, 117.42, 107.18, 70.12, 52.96, 45.83, 36.73, 28.48. HRMS Calculated for $\mathrm{C}_{17} \mathrm{H}_{18} \mathrm{BrNO}[\mathrm{M}+\mathrm{H}]^{+} 332.0650$, found 332.0644. HPLC: $\mathrm{t}_{\mathrm{R}}=16.50 \mathrm{~min}$, Agilent TC-C18(2) $250 \times 4.6 \mathrm{~mm}$ $5 \mu \mathrm{m}, 40{ }^{\circ} \mathrm{C}$, eluent A-60\%, eluent B-40\%.

1-(4-chlorophenyl)-3-(indolin-1-yl)propan-1-ol(7d): Light yellow solid. 43\% yield. m.p. 64.6-66.2 ${ }^{\circ} \mathrm{C} .{ }^{1} \mathrm{H}$ NMR $\left(400 \mathrm{MHz}, \mathrm{DMSO}-d_{6}\right) \delta: 7.38(\mathrm{~s}, 4 \mathrm{H}), 7.00(\mathrm{~d}, J=7.1 \mathrm{~Hz}, 1 \mathrm{H}), 6.96(\mathrm{t}, J=7.7 \mathrm{~Hz}, 1 \mathrm{H}), 6.54(\mathrm{t}, J=7.3 \mathrm{~Hz}, 1 \mathrm{H}), 6.40(\mathrm{~d}, J$ $=7.8 \mathrm{~Hz}, 1 \mathrm{H}), 5.39(\mathrm{~d}, J=4.6 \mathrm{~Hz}, 1 \mathrm{H}), 4.68-4.64(\mathrm{~m}, 1 \mathrm{H}), 3.30-3.24(\mathrm{~m}, 2 \mathrm{H}), 3.15-3.04(\mathrm{~m}, 2 \mathrm{H}), 2.86(\mathrm{t}, J=8.3 \mathrm{~Hz}$, 2H), $1.84-1.79$ (m, 2H). ${ }^{13} \mathrm{C}$ NMR (100 MHz, DMSO- $\left.d_{6}\right) \delta: 152.86,145.65,131.58,130.10,128.44(2 \mathrm{C}), 128.06(2 \mathrm{C})$, 127.54, 124.56, 117.42, 107.18, 70.11, 52.97, 45.85, 36.77, 28.48. HRMS Calculated for $\mathrm{C}_{17} \mathrm{H}_{18} \mathrm{ClNO}[\mathrm{M}+\mathrm{H}]^{+} 288.1155$, found 288.1141. HPLC: $t_{R}=15.62 \mathrm{~min}$, Agilent TC-C18(2) $250 \times 4.6 \mathrm{~mm} 5 \mu \mathrm{m}, 40{ }^{\circ} \mathrm{C}$, eluent A-60\%, eluent B-40\%.

3-(5-methoxyindolin-1-yl)-1-(4-methoxyphenyl)propan-1-ol(7e): Light yellow solid. 42\% yield. m.p. 51.1 $52.7^{\circ} \mathrm{C} .{ }^{1} \mathrm{H}$ NMR $\left(400 \mathrm{MHz}, \mathrm{DMSO}-d_{6}\right) \delta: 7.26(\mathrm{~d}, J=8.5 \mathrm{~Hz}, 2 \mathrm{H}), 6.88(\mathrm{~d}, J=8.5 \mathrm{~Hz}, 2 \mathrm{H}), 6.70(\mathrm{~d}, J=1.9 \mathrm{~Hz}, 1 \mathrm{H})$, $6.56(\mathrm{~d}, J=7.0 \mathrm{~Hz}, 1 \mathrm{H}), 6.32(\mathrm{~d}, J=8.4 \mathrm{~Hz}, 1 \mathrm{H}), 5.15(\mathrm{~d}, J=4.4 \mathrm{~Hz}, 1 \mathrm{H}), 4.62-4.57(\mathrm{~m}, 1 \mathrm{H}), 3.73(\mathrm{~s}, 3 \mathrm{H}), 3.63(\mathrm{~s}, 3 \mathrm{H})$, $3.18(\mathrm{t}, J=8.5 \mathrm{~Hz}, 2 \mathrm{H}), 2.97(\mathrm{t}, J=7.3 \mathrm{~Hz}, 2 \mathrm{H}), 2.81(\mathrm{t}, J=8.1 \mathrm{~Hz}, 2 \mathrm{H}), 1.86-1.74(\mathrm{~m}, 2 \mathrm{H}) .{ }^{13} \mathrm{C} \mathrm{NMR}(100 \mathrm{MHz}$, DMSO- $\left.d_{6}\right) \delta 158.58,152.65,147.32,138.67,131.71,127.35(2 \mathrm{C}), 113.86(2 \mathrm{C}), 112.06,112.03,107.78,70.49,55.94,55.47$, 53.78, 47.29, 37.10, 28.85. HRMS Calculated for $\mathrm{C}_{19} \mathrm{H}_{23} \mathrm{NO}_{3}[\mathrm{M}+\mathrm{H}]^{+}$314.1756, found 314.1748. HPLC: $\mathrm{t}_{\mathrm{R}}=7.27 \mathrm{~min}$, Agilent TC-C18(2) $250 \times 4.6 \mathrm{~mm} 5 \mu \mathrm{m}, 40{ }^{\circ} \mathrm{C}$, eluent A-60\%, eluent B-40\%. 
1-(3,4-dimethoxyphenyl)-3-(5-methoxyindolin-1-yl)propan-1-ol(7f): Light green solid. 40\% yield. m.p. $54.2-$ $56.9^{\circ} \mathrm{C} .{ }^{1} \mathrm{H}$ NMR $\left(300 \mathrm{MHz}, \mathrm{CDCl}_{3}\right) \delta: 6.96(\mathrm{~s}, 1 \mathrm{H}), 6.81(\mathrm{~m}, 2 \mathrm{H}), 6.76(\mathrm{~s}, 1 \mathrm{H}), 6.65(\mathrm{~d}, J=8.4 \mathrm{~Hz}, 1 \mathrm{H}), 6.49(\mathrm{~d}, J=8.1$ Hz, 1H), 4.93 (t, $J=6.0 \mathrm{~Hz}, 1 \mathrm{H}), 3.99(\mathrm{~s}, 1 \mathrm{H}), 3.89(\mathrm{~s}, 6 \mathrm{H}), 3.75(\mathrm{~s}, 3 \mathrm{H}), 3.42-3.23(\mathrm{~m}, 2 \mathrm{H}), 3.21-3.07(\mathrm{~m}, 2 \mathrm{H}), 2.95(\mathrm{t}$, $J=7.6 \mathrm{~Hz}, 2 \mathrm{H}), 2.04(\mathrm{q}, J=6.1 \mathrm{~Hz}, 2 \mathrm{H}) .{ }^{13} \mathrm{C}$ NMR $\left(100 \mathrm{MHz}, \mathrm{DMSO}-d_{6}\right) \delta 152.66,149.04,148.11,147.33,139.28,131.71$, 118.23, 112.06, 112.04, 112.01, 110.16, 107.77, 70.77, 56.04, 55.95, 55.89, 53.79, 47.31, 37.09, 28.86. HRMS Calculated for $\mathrm{C}_{20} \mathrm{H}_{25} \mathrm{NO}_{4}[\mathrm{M}+\mathrm{H}]^{+}$344.1862, found 344.1850. HPLC: $\mathrm{t}_{\mathrm{R}}=7.03 \mathrm{~min}$, Agilent TC-C18(2) $250 \times 4.6 \mathrm{~mm} 5 \mu \mathrm{m}, 40{ }^{\circ} \mathrm{C}$, eluent A-60\%, eluent B-40\%.

(furan-2-yl)-3-(5-methoxyindolin-1-yl)propan-1-ol(7g): Orange yellow solid. $42 \%$ yield. m.p. $36.4-38.1{ }^{\circ} \mathrm{C} .{ }^{1} \mathrm{H}$ NMR $\left(400 \mathrm{MHz}\right.$, DMSO- $\left.d_{6}\right) \delta: 7.57(\mathrm{~s}, 1 \mathrm{H}), 6.70(\mathrm{~s}, 1 \mathrm{H}), 6.57(\mathrm{~d}, J=8.3 \mathrm{~Hz}, 1 \mathrm{H}), 6.38(\mathrm{~d}, J=1.4 \mathrm{~Hz}, 1 \mathrm{H}), 6.34(\mathrm{~d}, J=$ $8.4 \mathrm{~Hz}, 1 \mathrm{H}), 6.26(\mathrm{~s}, 1 \mathrm{H}), 5.35(\mathrm{~d}, J=5.4 \mathrm{~Hz}, 1 \mathrm{H}), 4.65-4.61(\mathrm{~m}, 1 \mathrm{H}), 3.63(\mathrm{~s}, 3 \mathrm{H}), 3.23-3.18(\mathrm{~m}, 2 \mathrm{H}), 3.03-2.98(\mathrm{~m}$, 2H), 2.82 (t, $J=8.1 \mathrm{~Hz}, 2 \mathrm{H}), 1.97-1.91(\mathrm{~m}, 2 \mathrm{H}) .{ }^{13} \mathrm{C}$ NMR (100 MHz, DMSO-d $)$ ) $: 158.46,152.68,147.24,142.08$, 131.67, 112.07, 112.05, 110.60, 107.74, 105.74, 64.50, 55.95, 53.83, 46.89, 33.50, 28.85. HRMS Calculated for $\mathrm{C}_{16} \mathrm{H}_{19} \mathrm{NO}_{3}[\mathrm{M}+\mathrm{H}]^{+} 274.1443$, found 274.1435. HPLC: $\mathrm{t}_{\mathrm{R}}=6.65 \mathrm{~min}$, Agilent TC-C18(2) $250 \times 4.6 \mathrm{~mm} 5 \mu \mathrm{m}, 40{ }^{\circ} \mathrm{C}$, eluent A-60\%, eluent B-40\%.

1-(2-chlorophenyl)-3-(indolin-1-yl)propan-1-ol(7h): Light green solid. 41\% yield. m.p. $58.5-59.0^{\circ} \mathrm{C} .{ }^{1} \mathrm{H}$ NMR $\left(400 \mathrm{MHz}, \mathrm{DMSO}-d_{6}\right) \delta: 7.63(\mathrm{~d}, J=7.7 \mathrm{~Hz}, 1 \mathrm{H}), 7.36(\mathrm{t}, J=8.8 \mathrm{~Hz}, 2 \mathrm{H}), 7.26(\mathrm{t}, J=7.6 \mathrm{~Hz}, 1 \mathrm{H}), 7.01-6.94(\mathrm{~m}, 2 \mathrm{H})$, $6.53(\mathrm{t}, J=7.3 \mathrm{~Hz}, 1 \mathrm{H}), 6.43(\mathrm{~d}, J=7.8 \mathrm{~Hz}, 1 \mathrm{H}), 5.50(\mathrm{~d}, J=4.6 \mathrm{~Hz}, 1 \mathrm{H}), 5.04-4.97(\mathrm{~m}, 1 \mathrm{H}), 3.28-3.20(\mathrm{~m}, 2 \mathrm{H}), 3.12$ $-3.07(\mathrm{~m}, 2 \mathrm{H}), 2.85(\mathrm{t}, J=8.2 \mathrm{~Hz}, 2 \mathrm{H}), 1.97-1.87(\mathrm{~m}, 2 \mathrm{H}) .{ }^{13} \mathrm{C}$ NMR $\left(100 \mathrm{MHz}, \mathrm{DMSO}-d_{6}\right) \delta: 152.85,143.97,130.87$, $130.08,129.39,128.76,127.94,127.69,127.53,124.57,117.41,107.17,67.36,52.94,45.86,35.28,28.49$. HRMS Calculated for $\mathrm{C}_{17} \mathrm{H}_{18} \mathrm{ClNO}[\mathrm{M}+\mathrm{H}]^{+} 288.1155$, found 288.1143. HPLC: $\mathrm{t}_{\mathrm{R}}=15.92 \mathrm{~min}$, Agilent TC-C18(2) $250 \times 4.6 \mathrm{~mm}$ $5 \mu \mathrm{m}, 40{ }^{\circ} \mathrm{C}$, eluent A-60\%, eluent B- $40 \%$.

(4-fluorophenyl)-3-(indolin-1-yl)propan-1-ol(7i): Light yellow solid. $45 \%$ yield. m.p. $43.2-44.8^{\circ} \mathrm{C} .{ }^{1} \mathrm{H}$ NMR (400 MHz, DMSO-d $\left.)_{6}\right) \delta: 7.40-7.37(\mathrm{~m}, 2 \mathrm{H}), 7.14(\mathrm{t}, J=8.9 \mathrm{~Hz}, 2 \mathrm{H}), 7.00(\mathrm{~d}, J=7.1 \mathrm{~Hz}, 1 \mathrm{H}), 6.96(\mathrm{t}, J=7.7 \mathrm{~Hz}, 1 \mathrm{H}), 6.54$ (t, $J=7.3 \mathrm{~Hz}, 1 \mathrm{H}), 6.39$ (d, $J=7.8 \mathrm{~Hz}, 1 \mathrm{H}), 5.34(\mathrm{~d}, J=4.6 \mathrm{~Hz}, 1 \mathrm{H}), 4.68-4.64(\mathrm{~m}, 1 \mathrm{H}), 3.30-3.24(\mathrm{~m}, 2 \mathrm{H}), 3.13-$ $3.04(\mathrm{~m}, 2 \mathrm{H}), 2.85(\mathrm{t}, J=8.3 \mathrm{~Hz}, 2 \mathrm{H}), 1.84-1.79(\mathrm{~m}, 2 \mathrm{H}) .{ }^{13} \mathrm{C}$ NMR $\left(100 \mathrm{MHz}, \mathrm{DMSO}-d_{6}\right) \delta: 161.55\left(J_{\mathrm{C}-\mathrm{F}}=240.9 \mathrm{~Hz}\right)$, $152.89,142.81\left(J_{\mathrm{C}-\mathrm{F}}=2.8 \mathrm{~Hz}\right), 130.11,128.05\left(J_{\mathrm{C}-\mathrm{F}}=8.0 \mathrm{~Hz}, 2 \mathrm{C}\right), 127.54,124.56,117.41,115.15\left(J_{\mathrm{C}-\mathrm{F}}=21.0 \mathrm{~Hz}, 2 \mathrm{C}\right)$, 107.18, 70.15, 52.97, 45.91, 36.89, 28.48. HRMS Calculated for $\mathrm{C}_{17} \mathrm{H}_{18} \mathrm{FNO}[\mathrm{M}+\mathrm{H}]^{+}$272.1451, found 272.1801. HPLC: $\mathrm{t}_{\mathrm{R}}=12.45 \mathrm{~min}$, Agilent TC-C18(2) $250 \times 4.6 \mathrm{~mm} 5 \mu \mathrm{m}, 40{ }^{\circ} \mathrm{C}$, eluent A-60\%, eluent B- $40 \%$. 
1-(furan-2-yl)-3-(indolin-1-yl)propan-1-ol(7j): Light yellow solid. $44 \%$ yield. m.p. $31.6-32.4^{\circ} \mathrm{C} .{ }^{1} \mathrm{H}$ NMR $(400$ MHz, DMSO-d $) \delta: 7.59-7.55(\mathrm{~m}, 1 \mathrm{H}), 7.00(\mathrm{~d}, J=7.1 \mathrm{~Hz}, 1 \mathrm{H}), 6.96(\mathrm{t}, J=7.6 \mathrm{~Hz}, 1 \mathrm{H}), 6.54(\mathrm{t}, J=7.3 \mathrm{~Hz}, 1 \mathrm{H}), 6.41-$ $6.38(\mathrm{~m}, 2 \mathrm{H}), 6.27(\mathrm{~d}, J=3.1 \mathrm{~Hz}, 1 \mathrm{H}), 5.37(\mathrm{~d}, J=5.4 \mathrm{~Hz}, 1 \mathrm{H}), 4.65-4.60(\mathrm{~m}, 1 \mathrm{H}), 3.32-3.26(\mathrm{~m}, 2 \mathrm{H}), 3.16-3.05(\mathrm{~m}$, 2H), $2.86(\mathrm{t}, J=8.3 \mathrm{~Hz}, 2 \mathrm{H}), 1.98-1.92(\mathrm{~m}, 2 \mathrm{H}) .{ }^{13} \mathrm{C}$ NMR (100 MHz, DMSO-d 6 ) $\delta: 158.42,152.86,142.10,130.06$, 127.54, 124.57, 117.40, 110.61, 107.11, 105.76, 64.44, 53.04, 45.63, 33.34, 28.48. HRMS Calculated for $\mathrm{C}_{15} \mathrm{H}_{17} \mathrm{NO}_{2}$ $[\mathrm{M}+\mathrm{H}]^{+} 244.1337$, found 244.1337. HPLC: $\mathrm{t}_{\mathrm{R}}=8.19 \mathrm{~min}$, Agilent TC-C18(2) $250 \times 4.6 \mathrm{~mm} 5 \mu \mathrm{m}, 40{ }^{\circ} \mathrm{C}$, eluent A-60\%, eluent B-40\%.

3-(indolin-1-yl)-1-(4-methoxyphenyl)propan-1-ol(7k): White solid. 42\% yield. m.p. 57.4-59.2 ${ }^{\circ} \mathrm{C} .{ }^{1} \mathrm{H}$ NMR (400 MHz, DMSO-d 6 ) $\delta: 7.26(\mathrm{~d}, J=8.6 \mathrm{~Hz}, 2 \mathrm{H}), 7.00(\mathrm{~d}, J=7.1 \mathrm{~Hz}, 1 \mathrm{H}), 6.96(\mathrm{t}, J=7.6 \mathrm{~Hz}, 1 \mathrm{H}), 6.88(\mathrm{~d}, J=8.6 \mathrm{~Hz}, 2 \mathrm{H})$, $6.53(\mathrm{t}, J=7.3 \mathrm{~Hz}, 1 \mathrm{H}), 6.38(\mathrm{~d}, J=7.8 \mathrm{~Hz}, 1 \mathrm{H}), 5.17(\mathrm{~d}, J=4.4 \mathrm{~Hz}, 1 \mathrm{H}), 4.62-4.56(\mathrm{~m}, 1 \mathrm{H}), 3.73(\mathrm{~s}, 3 \mathrm{H}), 3.30-3.23$ $(\mathrm{m}, 2 \mathrm{H}), 3.07$ (t, $J=7.3 \mathrm{~Hz}, 2 \mathrm{H}), 2.85(\mathrm{t}, J=8.3 \mathrm{~Hz}, 2 \mathrm{H}), 1.86-1.77(\mathrm{~m}, 2 \mathrm{H}) .{ }^{13} \mathrm{C}$ NMR $\left(100 \mathrm{MHz}, \mathrm{DMSO}-d_{6}\right) \delta: 158.60$, 152.93, 138.62, 130.10, 127.53, 127.35(2C), 124.55, 117.36, 113.88(2C), 107.16, 70.43, 55.48, 52.99, 46.02, 36.90, 28.49. HRMS Calculated for $\mathrm{C}_{18} \mathrm{H}_{21} \mathrm{NO}_{2}[\mathrm{M}+\mathrm{H}]^{+}$284.1650, found 284.1646. HPLC: $\mathrm{t}_{\mathrm{R}}=9.99$ min, Agilent TC-C18(2) $250 \times 4.6 \mathrm{~mm} 5 \mu \mathrm{m}, 40{ }^{\circ} \mathrm{C}$, eluent A-60\%, eluent B- $40 \%$.

3-(indolin-1-yl)-1-(thiophen-2-yl)propan-1-ol(7l): Light yellow solid. 43\% yield. m.p. $28.6-30.1{ }^{\circ} \mathrm{C} .{ }^{1} \mathrm{H}$ NMR (400 MHz, DMSO-d 6 ) $\delta: 7.41-7.37(\mathrm{~m}, 1 \mathrm{H}), 7.01(\mathrm{~d}, J=7.1 \mathrm{~Hz}, 1 \mathrm{H}), 6.99-6.93(\mathrm{~m}, 3 \mathrm{H}), 6.54(\mathrm{t}, J=7.3 \mathrm{~Hz}, 1 \mathrm{H}), 6.41(\mathrm{~d}, J$ $=7.8 \mathrm{~Hz}, 1 \mathrm{H}), 5.66(\mathrm{~d}, J=4.9 \mathrm{~Hz}, 1 \mathrm{H}), 4.93-4.87(\mathrm{~m}, 1 \mathrm{H}), 3.32-3.25(\mathrm{~m}, 2 \mathrm{H}), 3.17-3.07(\mathrm{~m}, 2 \mathrm{H}), 2.87(\mathrm{t}, J=8.3 \mathrm{~Hz}$, 2H), 1.97 - 1.89 (m, 2H). ${ }^{13} \mathrm{C}$ NMR (100 MHz, DMSO-d $) \delta: 152.87,151.12,130.10,127.56,127.01,124.59,124.54$, 123.33, 117.45, 107.18, 66.90, 53.06, 45.79, 37.06, 28.49. HRMS Calculated for $\mathrm{C}_{15} \mathrm{H}_{17} \mathrm{NOS}[\mathrm{M}+\mathrm{H}]^{+} 260.1109$, found 260.1105. HPLC: $\mathrm{t}_{\mathrm{R}}=8.42 \mathrm{~min}$, Agilent TC-C18(2) $250 \times 4.6 \mathrm{~mm} 5 \mu \mathrm{m}, 40{ }^{\circ} \mathrm{C}$, eluent A-60\%, eluent B-40\%.

3-(5-methoxyindolin-1-yl)-1-(3,5,6-trimethylpyrazin-2-yl)propan-1-ol(7m): Light green solid. 8\% yield. m.p. 35.7-37.6 ${ }^{\circ} \mathrm{C} .{ }^{1} \mathrm{H}$ NMR (400 MHz, DMSO-d $\left.d_{6}\right) \delta: 6.70(\mathrm{~s}, 1 \mathrm{H}), 6.56(\mathrm{~d}, J=8.2 \mathrm{~Hz}, 1 \mathrm{H}), 6.36(\mathrm{~d}, J=8.3 \mathrm{~Hz}, 1 \mathrm{H}), 5.16(\mathrm{~d}, J$ $=6.0 \mathrm{~Hz}, 1 \mathrm{H}), 4.87-4.78(\mathrm{~m}, 1 \mathrm{H}), 3.63(\mathrm{~s}, 3 \mathrm{H}), 3.20(\mathrm{t}, J=8.0 \mathrm{~Hz}, 2 \mathrm{H}), 3.04(\mathrm{t}, J=6.8 \mathrm{~Hz}, 2 \mathrm{H}), 2.81(\mathrm{t}, J=7.8 \mathrm{~Hz}, 2 \mathrm{H})$, 2.47(s, 3H), 2.43(s, 3H), 2.41(s, 3H), $2.04-1.94$ (m, 2H). ${ }^{13} \mathrm{C}$ NMR (100 MHz, DMSO-d $)$ ): 152.62, 152.13, 149.50, 147.98, 147.79, 147.25, 131.64, 112.04, 112.03, 107.76, 68.78, 55.95, 53.76, 47.13, 33.16, 28.84, 21.54(2C), 20.75. HRMS Calculated for $\mathrm{C}_{19} \mathrm{H}_{25} \mathrm{~N}_{3} \mathrm{O}_{2}[\mathrm{M}+\mathrm{H}]^{+}$328.2025, found 328.2007. HPLC: $\mathrm{t}_{\mathrm{R}}=7.52 \mathrm{~min}$, Agilent TC-C18(2) $250 \times$ $4.6 \mathrm{~mm} 5 \mu \mathrm{m}, 40{ }^{\circ} \mathrm{C}$, eluent A- $60 \%$, eluent B- $40 \%$. 
1-(benzo[d][1,3]dioxol-4-yl)-3-(indolin-1-yl)propan-1-ol(7n): Yellow solid. 41\% yield. m.p. $44.9-46.5^{\circ} \mathrm{C} .{ }^{1} \mathrm{H}$ NMR (400 MHz, DMSO-d $)) \delta: 7.02-6.93(\mathrm{~m}, 3 \mathrm{H}), 6.82(\mathrm{q}, J=7.8 \mathrm{~Hz}, 2 \mathrm{H}), 6.54(\mathrm{t}, J=7.3 \mathrm{~Hz}, 1 \mathrm{H}), 6.40(\mathrm{~d}, J=7.7 \mathrm{~Hz}$, $1 \mathrm{H}), 5.97(\mathrm{~d}, J=4.7 \mathrm{~Hz}, 2 \mathrm{H}), 5.34(\mathrm{~d}, J=4.7 \mathrm{~Hz}, 1 \mathrm{H}), 4.79(\mathrm{dd}, J=7.4,3.5 \mathrm{~Hz}, 1 \mathrm{H}), 3.33-3.21(\mathrm{~m}, 2 \mathrm{H}), 3.16-3.04(\mathrm{~m}$, 2H), $2.85(\mathrm{t}, J=8.2 \mathrm{~Hz}, 2 \mathrm{H}), 1.94-1.82(\mathrm{~m}, 2 \mathrm{H}) .{ }^{13} \mathrm{C}$ NMR (100 MHz, DMSO- $\left.d_{6}\right) \delta: 152.92,147.07,143.81,130.07$, $128.08,127.53,124.55,121.81,119.71,117.40,107.40,107.17,101.04,65.61,52.96,45.79,34.98,28.48$. HRMS Calculated for $\mathrm{C}_{18} \mathrm{H}_{19} \mathrm{NO}_{3}[\mathrm{M}+\mathrm{H}]^{+} 298.1443$, found 298.1434. HPLC: $\mathrm{t}_{\mathrm{R}}=8.14 \mathrm{~min}$, Agilent TC-C18(2) $250 \times 4.6 \mathrm{~mm} 5$ $\mu \mathrm{m}, 40{ }^{\circ} \mathrm{C}$, eluent A-60\%, eluent B- $40 \%$.

3-(indolin-1-yl)-1-(p-tolyl)propan-1-ol(7o): Light yellow solid. 41\% yield. m.p. 49.6-52.2 ${ }^{\circ} \mathrm{C} .{ }^{1} \mathrm{H}$ NMR $(400 \mathrm{MHz}$, DMSO- $\left.d_{6}\right) \delta: 7.23(\mathrm{~d}, J=7.7 \mathrm{~Hz}, 2 \mathrm{H}), 7.13(\mathrm{~d}, J=7.7 \mathrm{~Hz}, 2 \mathrm{H}), 7.00(\mathrm{~d}, J=7.1 \mathrm{~Hz}, 1 \mathrm{H}), 6.96(\mathrm{t}, J=7.7 \mathrm{~Hz}, 1 \mathrm{H}), 6.54(\mathrm{t}$, $J=7.3 \mathrm{~Hz}, 1 \mathrm{H}), 6.39$ (d, $J=7.8 \mathrm{~Hz}, 1 \mathrm{H}), 5.22(\mathrm{~d}, J=4.3 \mathrm{~Hz}, 1 \mathrm{H}), 4.64-4.57$ (m, 1H), $3.30-3.23$ (m, 2H), $3.11-3.04$ $(\mathrm{m}, 2 \mathrm{H}), 2.86(\mathrm{t}, J=8.3 \mathrm{~Hz}, 2 \mathrm{H}), 2.28(\mathrm{~s}, 3 \mathrm{H}), 1.85-1.77(\mathrm{~m}, 2 \mathrm{H}) .{ }^{13} \mathrm{C}$ NMR (100 MHz, DMSO-d 6$) \delta: 152.92,143.64$, 136.10, 130.10, 129.04(2C), 127.54, 126.14(2C), 124.56, 117.38, 107.17, 70.62, 52.98, 45.98, 36.90, 28.48, 21.18. HRMS Calculated for $\mathrm{C}_{18} \mathrm{H}_{21} \mathrm{NO}[\mathrm{M}+\mathrm{H}]^{+} 268.1701$, found 268.1696. HPLC: $\mathrm{t}_{\mathrm{R}}=13.75 \mathrm{~min}$, Agilent TC-C18(2) $250 \times 4.6 \mathrm{~mm} 5$ $\mu \mathrm{m}, 40{ }^{\circ} \mathrm{C}$, eluent A- $60 \%$, eluent B- $40 \%$.

1-(3-chlorophenyl)-3-(indolin-1-yl)propan-1-ol(7p): Light yellow solid. 43\% yield. m.p. 56.7-58.3 ${ }^{\circ} \mathrm{C} .{ }^{1} \mathrm{H}$ NMR $\left(400 \mathrm{MHz}, \mathrm{DMSO}-d_{6}\right) \delta: 7.41(\mathrm{~s}, 1 \mathrm{H}), 7.38-7.27(\mathrm{~m}, 3 \mathrm{H}), 7.00(\mathrm{~d}, J=7.1 \mathrm{~Hz}, 1 \mathrm{H}), 6.96(\mathrm{t}, J=7.7 \mathrm{~Hz}, 1 \mathrm{H}), 6.54(\mathrm{t}, J=$ $7.3 \mathrm{~Hz}, 1 \mathrm{H}), 6.40(\mathrm{~d}, J=7.8 \mathrm{~Hz}, 1 \mathrm{H}), 5.46(\mathrm{~d}, J=4.7 \mathrm{~Hz}, 1 \mathrm{H}), 4.71-4.63(\mathrm{~m}, 1 \mathrm{H}), 3.33-3.22(\mathrm{~m}, 2 \mathrm{H}), 3.17-3.05(\mathrm{~m}$, 2H), $2.86(\mathrm{t}, J=8.3 \mathrm{~Hz}, 2 \mathrm{H}), 1.87-1.77(\mathrm{~m}, 2 \mathrm{H}) .{ }^{13} \mathrm{C}$ NMR (100 MHz, DMSO-d $) \delta: 152.85,149.35,133.33,130.41$, 130.10, 127.53, 127.05, 126.02, 124.87, 124.57, 117.42, 107.18, 70.15, 52.95, 45.83, 36.72, 28.48. HRMS Calculated for $\mathrm{C}_{17} \mathrm{H}_{18} \mathrm{ClNO}[\mathrm{M}+\mathrm{H}]^{+}$288.1155, found 288.1146. HPLC: $\mathrm{t}_{\mathrm{R}}=15.07 \mathrm{~min}$, Agilent TC-C18(2) $250 \times 4.6 \mathrm{~mm} 5 \mu \mathrm{m}, 40{ }^{\circ} \mathrm{C}$, eluent A-60\%, eluent B-40\%.

1-(benzo[d][1,3]dioxol-5-yl)-3-(indolin-1-yl)propan-1-ol(7q): Light green solid. 45\% yield. m.p. 25.6-27.6 ${ }^{\circ} \mathrm{C} .{ }^{1} \mathrm{H}$ NMR (400 MHz, DMSO-d $) \delta: 7.00(\mathrm{~d}, J=7.1 \mathrm{~Hz}, 1 \mathrm{H}), 6.95(\mathrm{t}, J=8.0 \mathrm{~Hz}, 1 \mathrm{H}), 6.91(\mathrm{~s}, 1 \mathrm{H}), 6.86-6.75(\mathrm{~m}, 2 \mathrm{H}), 6.53(\mathrm{t}$, $J=7.3 \mathrm{~Hz}, 1 \mathrm{H}), 6.39$ (d, $J=7.7 \mathrm{~Hz}, 1 \mathrm{H}), 5.97(\mathrm{~s}, 2 \mathrm{H}), 5.22(\mathrm{~d}, J=4.4 \mathrm{~Hz}, 1 \mathrm{H}), 4.60-4.54(\mathrm{~m}, 1 \mathrm{H}), 3.31-3.20(\mathrm{~m}, 2 \mathrm{H})$, $3.06(\mathrm{t}, J=7.0 \mathrm{~Hz}, 2 \mathrm{H}), 2.85(\mathrm{t}, J=8.2 \mathrm{~Hz}, 2 \mathrm{H}), 1.84-1.75(\mathrm{~m}, 2 \mathrm{H}) .{ }^{13} \mathrm{C}$ NMR $\left(100 \mathrm{MHz}, \mathrm{DMSO}-d_{6}\right) \delta: 152.92,147.58$, $146.35,140.81,130.11,127.53,124.55,119.29,117.38,108.19,107.18,106.70,101.14,70.66,52.98,45.99,36.93$, 28.48. HRMS Calculated for $\mathrm{C}_{18} \mathrm{H}_{19} \mathrm{NO}_{3}[\mathrm{M}+\mathrm{H}]^{+}$298.1443, found 298.1426. HPLC: $\mathrm{t}_{\mathrm{R}}=9.47$ min, Agilent TC-C18(2) $250 \times 4.6 \mathrm{~mm} 5 \mu \mathrm{m}, 40{ }^{\circ} \mathrm{C}$, eluent A-60\%, eluent B-40\%. 
(benzo[d][1,3]dioxol-5-yl)-3-(5-methoxyindolin-1-yl)propan-1-ol(7r): Yellow solid. 43\% yield. m.p. 80.6-82.3 ${ }^{\circ} \mathrm{C}$. ${ }^{1} \mathrm{H}$ NMR (400 MHz, DMSO-d $\left.)\right) \delta: 6.91(\mathrm{~s}, 1 \mathrm{H}), 6.86-6.77(\mathrm{~m}, 2 \mathrm{H}), 6.70(\mathrm{~s}, 1 \mathrm{H}), 6.56(\mathrm{~d}, J=8.1 \mathrm{~Hz}, 1 \mathrm{H}), 6.33(\mathrm{~d}, J=$ $8.3 \mathrm{~Hz}, 1 \mathrm{H}), 5.97(\mathrm{~s}, 2 \mathrm{H}), 5.21(\mathrm{~d}, J=4.4 \mathrm{~Hz}, 2 \mathrm{H}), 4.60-4.53(\mathrm{~m}, 1 \mathrm{H}), 3.63(\mathrm{~s}, 3 \mathrm{H}), 3.18(\mathrm{t}, J=6.8 \mathrm{~Hz}, 2 \mathrm{H}), 2.97(\mathrm{t}, J=$ $6.8 \mathrm{~Hz}, 2 \mathrm{H}), 2.81$ (t, $J=7.8 \mathrm{~Hz}, 2 \mathrm{H}), 1.83-1.74(\mathrm{~m}, 2 \mathrm{H}) .{ }^{13} \mathrm{C}$ NMR (100 MHz, DMSO-d $) \delta: 152.67,147.57,147.29$, 146.33, 140.85, 131.72, 119.29, 112.07, 112.05, 108.18, 107.80, 106.70, 101.13, 70.73, 55.96, 53.77, 47.26, 37.12, 28.85. HRMS Calculated for $\mathrm{C}_{19} \mathrm{H}_{21} \mathrm{NO}_{4}[\mathrm{M}+\mathrm{H}]^{+} 328.1549$, found 328.1531. HPLC: $\mathrm{t}_{\mathrm{R}}=7.66 \mathrm{~min}$, Agilent TC-C18(2) $250 \times 4.6$ mm $5 \mu \mathrm{m}, 40{ }^{\circ} \mathrm{C}$, eluent A-60\%, eluent B-40\%.

3-(indolin-1-yl)-1-(thiophen-2-yl)propan-1-one(61): Yellow solid. 45\% yield. m.p. 50.0-51.3 ${ }^{\circ} \mathrm{C} .{ }^{1} \mathrm{H}$ NMR $(400$ MHz, DMSO- $\left.d_{6}\right) \delta: 8.03-7.99(\mathrm{~m}, 2 \mathrm{H}), 7.27-7.23(\mathrm{~m}, 1 \mathrm{H}), 7.02-6.97(\mathrm{~m}, 2 \mathrm{H}), 6.58-6.51(\mathrm{~m}, 2 \mathrm{H}), 3.44(\mathrm{t}, J=6.9$ $\mathrm{Hz}, 2 \mathrm{H}), 3.33$ (t, $J=6.9 \mathrm{~Hz}, 2 \mathrm{H}), 3.23(\mathrm{t}, J=6.9 \mathrm{~Hz}, 2 \mathrm{H}), 2.85$ (t, $J=8.3 \mathrm{~Hz}, 2 \mathrm{H}) .{ }^{13} \mathrm{C}$ NMR $\left(100 \mathrm{MHz}, \mathrm{DMSO}-d_{6}\right) \delta$ : 192.53, 152.34, 144.38, 135.37, 133.94, 130.06, 129.23, 127.60, 124.64, 117.68, 107.33, 53.03, 44.54, 36.53, 28.46. HRMS Calculated for $\mathrm{C}_{15} \mathrm{H}_{15} \mathrm{NOS}[\mathrm{M}+\mathrm{H}]^{+}$258.0952, found 258.0948. HPLC: $\mathrm{t}_{\mathrm{R}}=10.09 \mathrm{~min}$, Agilent TC-C18(2) $250 \times$ $4.6 \mathrm{~mm} 5 \mu \mathrm{m}, 40{ }^{\circ} \mathrm{C}$, eluent A-70\%, eluent B-30\%.

1-(4-fluorophenyl)-3-(indolin-1-yl)propan-1-one(6i): Light yellow solid. 47\% yield. m.p. 30.1-32.. $0{ }^{\circ} \mathrm{C} .{ }^{1} \mathrm{H}$ NMR (400 MHz, DMSO-d $\left.)_{6}\right) \delta: 8.11-8.04(\mathrm{~m}, 2 \mathrm{H}), 7.35(\mathrm{t}, J=8.8 \mathrm{~Hz}, 2 \mathrm{H}), 7.03-6.95(\mathrm{~m}, 2 \mathrm{H}), 6.59-6.50(\mathrm{~m}, 2 \mathrm{H}), 3.44(\mathrm{t}, J$ $=6.8 \mathrm{~Hz}, 2 \mathrm{H}), 3.36-3.26(\mathrm{~m}, 4 \mathrm{H}), 2.85(\mathrm{t}, J=8.2 \mathrm{~Hz}, 2 \mathrm{H}) .{ }^{13} \mathrm{C}$ NMR $\left(100 \mathrm{MHz}, \mathrm{DMSO}-d_{6}\right) \delta: 198.16,165.51\left(J_{C-F}=\right.$ $250.2 \mathrm{~Hz}), 152.44,133.90\left(J_{C-F}=2.8 \mathrm{~Hz}\right), 131.43\left(J_{C-F}=9.4 \mathrm{~Hz}, 2 \mathrm{C}\right), 130.09,127.58,124.62,117.63,116.15\left(J_{C-F}=21.7\right.$ $\mathrm{Hz}, 2 \mathrm{C}), 107.31,53.05,44.27,35.99,28.46$. HRMS Calculated for $\mathrm{C}_{17} \mathrm{H}_{16} \mathrm{FNO}[\mathrm{M}+\mathrm{H}]^{+}$270.1294, found 270.1291. HPLC: $\mathrm{t}_{\mathrm{R}}=9.94 \mathrm{~min}$, Agilent TC-C18(2) $250 \times 4.6 \mathrm{~mm} 5 \mu \mathrm{m}, 40{ }^{\circ} \mathrm{C}$, eluent A-70\%, eluent B-30\%.

1-(2-chlorophenyl)-3-(indolin-1-yl)propan-1-one(6h): Yellow oil. 43\% yield. m.p. 27.6-29.1 ${ }^{\circ} \mathrm{C}{ }^{1} \mathrm{H}$ NMR (400 MHz, DMSO-d $\left.d_{6}\right) \delta: 7.66(\mathrm{~d}, J=7.6 \mathrm{~Hz}, 1 \mathrm{H}), 7.57-7.49(\mathrm{~m}, 2 \mathrm{H}), 7.45(\mathrm{t}, J=7.7 \mathrm{~Hz}, 1 \mathrm{H}), 7.01(\mathrm{~d}, J=7.2 \mathrm{~Hz}, 1 \mathrm{H}), 6.97$ (t, $J=7.8 \mathrm{~Hz}, 1 \mathrm{H}), 6.56$ (t, $J=7.3 \mathrm{~Hz}, 1 \mathrm{H}), 6.47(\mathrm{~d}, J=7.8 \mathrm{~Hz}, 1 \mathrm{H}), 3.41(\mathrm{t}, J=6.8 \mathrm{~Hz}, 2 \mathrm{H}), 3.29(\mathrm{t}, J=8.4 \mathrm{~Hz}, 2 \mathrm{H})$, $3.21(\mathrm{t}, J=6.8 \mathrm{~Hz}, 2 \mathrm{H}), 2.85$ (t, $J=8.2 \mathrm{~Hz}, 2 \mathrm{H}) .{ }^{13} \mathrm{C}$ NMR (100 MHz, DMSO- $\left.d_{6}\right) \delta: 202.13,152.28,139.13,132.68$, $130.85,130.12$, 129.99, 129.60, 127.88, 127.57, 124.65, 117.78, 107.32, 53.02, 44.13, 40.19, 28.47. HRMS Calculated for $\mathrm{C}_{17} \mathrm{H}_{16} \mathrm{ClNO}[\mathrm{M}+\mathrm{H}]^{+}$286.0998, found 286.0988. HPLC: $\mathrm{t}_{\mathrm{R}}=11.44 \mathrm{~min}$, Agilent TC-C18(2) $250 \times 4.6 \mathrm{~mm} 5 \mu \mathrm{m}, 40{ }^{\circ} \mathrm{C}$, eluent A-70\%, eluent B-30\%. 


\subsection{Biological activity}

\subsubsection{Protective Activity against Oxidative Stress.}

The RAW264.7 cells in logarithmic growth phase were seeded at a density of $1 \times 10^{4}$ cells/well in a 96-well plate, and cultured at $37{ }^{\circ} \mathrm{C}$ with $5 \% \mathrm{CO}_{2}$, until the cells were $90 \%$ confluent, then cultured in serum-free base incubation for $2 \mathrm{~h}$ to synchronize the cells. Subsequently, the supernatant was discarded, and the EMEM medium containing each compound $(0.1 \mathrm{nM}, 10 \mathrm{nM}, 100 \mathrm{nM})$ was added and incubated for $2 \mathrm{~h}$, and then the medium was replaced with $\mathrm{H}_{2} \mathrm{O}_{2}(100 \mu \mathrm{M})$ and the concentration was $(0,1 \mathrm{nM}, 10 \mathrm{nM}, 100 \mathrm{nM})$ drug medium continued to incubate with the cells for $24 \mathrm{~h}, 4 \mathrm{~h}$ before the end of the incubation, add $20 \mu \mathrm{L}$ MTT solution $(5 \mathrm{mg} / \mathrm{mL})$ to each well. After the incubation, discard the supernatant of each well, add $150 \mu \mathrm{L}$ DMSO to each well, place on a cell shaker for 10 minutes, and measure the OD 570 with a microplate reader after the crystals are fully dissolved ${ }^{[24]}$.

\subsubsection{Protective Activity against OGD/R-induced damage in rat cortical neuron cells}

The cells that grew to about 7 days were selected for in vitro OGD/R model. Adjust the cell density and seed it in a 12-well culture plate with a cell density of $4 \times 10^{4}$. Using DMEM medium containing $1 \%$ FBS and the corresponding concentration of medicine, the OGD/R model was prepared after $24 \mathrm{~h}$ of routine culture. First change the medium to DMEM medium without glucose and serum, and at the same time place the cells in a tri-gas incubator containing $5 \% \mathrm{CO}_{2}$ and $95 \% \mathrm{~N}_{2}$ for $2 \mathrm{~h}$ to complete the hypoxia process; then change the cell medium to complete DMEM medium, and place the cells in an incubator containing 5\% $\mathrm{CO}_{2}$ for $24 \mathrm{~h}$ to complete the reoxygenation process. $4 \mathrm{~h}$ before the end of the incubation, add $20 \mu \mathrm{L}$ of MTT solution $(5 \mathrm{mg} / \mathrm{mL})$ to each well. After the incubation, discard the supernatant of each well, add $150 \mu \mathrm{L}$ DMSO to each well, shake on a cell shaker for 10 minutes, and measure $\mathrm{OD}_{570}$ with a microplate reader after the crystals are fully dissolved ${ }^{[25]}$.

\subsubsection{GluN2B-containing NMDA Competitive binding experiment of receptors}

The compound was dissolved in DMSO to prepare a stock solution with a concentration of $1 \mathrm{mM}$, and the working solution concentration was 5,20 , and $80 \mathrm{nM}$. Add $50 \mu \mathrm{L}$ of Tris- $\mathrm{HCl}$ buffer containing [3H]Ifenprodil (50 nM) and GBR-12909 $(50 \mu \mathrm{M})$ to $400 \mu \mathrm{L}$ of membrane suspension. Take $45 \mu \mathrm{L}$ of membrane suspension, add $5 \mu \mathrm{L}$ of DMSO to the reaction system of Blank group and [3H]Ifenprodil control group; add $5 \mu \mathrm{L}$ to the reaction system of [3H]Ifenprodil non-specific binding control group to inhibit the GluN2B subtype of selective NMDA receptor at a concentration of 1000 $\mu \mathrm{M}$ Discontinuing agent Ro25-6981; $5 \mu \mathrm{L}$ of the test compound working solution with concentrations of 5, 20, $80 \mathrm{nM}$ was added to the reaction system of the test group, mixed well, and incubated at $4^{\circ} \mathrm{C}$ for $2 \mathrm{~h}$. The reaction was terminated by filtering with a microplate filter, and the microplate filter was washed 3 times with $3 \mathrm{~mL}$ of pre-cooled Tris- $\mathrm{HCl}$ buffer $(\mathrm{pH}=7.4)$. The radioactivity of the eluate is measured in $5 \mathrm{ml}$ OptiphaseHisafe 3 with an efficiency of $40 \%$ using a scintillation counter ${ }^{[26]}$. 


\subsubsection{Anti-inflammatory activity in vitro.}

BV2 cells in the logarithmic growth phase were seeded in a 96 -well plate at $5 \times 10^{3}$ cells/well, cultured at $37^{\circ} \mathrm{C}$ and $5 \%$ $\mathrm{CO}_{2}$ until the cells were $90 \%$ confluent, and then incubated with serum-free DMEM medium $2 \mathrm{~h}$ to synchronize the cells. Subsequently, the supernatant was discarded and the BV2 cells were incubated for $2 \mathrm{~h}$ with compounds at concentrations $(0.1 \mu \mathrm{M}, 1 \mu \mathrm{M}, 10 \mu \mathrm{M})$, and then the medium was replaced with a medium containing LPS (200 $\mathrm{ng} / \mathrm{ml})$ and incubated for another $8 \mathrm{~h}$. The cells treated with no LPS and drugs and no drugs only added to LPS were used as the blank control group and the LPS control group. After the incubation, collect the cell supernatant and freeze it at $-80^{\circ} \mathrm{C}$ for later use. The levels of TNF- $\alpha$, IL-6 and NO in the cell supernatant were determined according to the ELISA kit instructions. Each test is repeated 3 times $^{[27]}$.

\subsubsection{Animal model of focal cerebral ischemia.}

These male rats $(250 \sim 300 \mathrm{~g}$ in weight) were subjected to a transient MCAO model using an intraluminal thread. Specifically, rats were anesthetized with $10 \%$ chloral hydrate $(0.2 \mathrm{ml} / 10 \mathrm{~g})$ intraperitoneally (i. p.). The left common carotid artery (CCA), external carotid artery (ECA), and internal carotid artery (ICA) were exposed and carefully isolated from the vagus nerve. The pterygopalatine branch of the ICA was sealed with an electric coagulator. The distal end of the ECA was ligated with a 4-0 silk suture. A $25-\mathrm{mm}$ long nylon filament $(0.26 \mathrm{~mm})$, with its tip dipped in heparin before use, was inserted into the ECA lumen through a small puncture, and gently advanced into the lumen to a distance of 20 $\mathrm{mm}$ until the tip of the filament blocked the origin of the middle cerebral artery (MCA). After 90 min of ischemia, the nylon filament was withdrawn from the internal carotid artery lumen to establish reperfusion. The same procedure was performed on sham-operated rats, but the middle cerebral artery was not blocked. The neurological deficits were scored after $10 \mathrm{~min}$. These rats with obvious neurological deficits were considered successful. The body temperature of the rats was maintained at $37 \pm 0.5^{\circ} \mathrm{C}$ during the operation ${ }^{[28-29]}$.

\subsubsection{Morris water maze test}

Positioning navigation experiment: Rats were put into water from four different quadrants at nine o'clock every morning and were trained four times. Recording the time that the rat seeks and climbs on the columnar platform, that is the latency of rats escape. This experimental process was continued for three days and the detection time is set to 120 $\mathrm{S}^{[28-29]}$,

\section{Measurement of neurological deficit score}

The neurological deficit of each rat, according to Zea-Longa method using a 5-point scales (no neuro-logical deficit = 0 ; failure to extend right paw fully $=1$; circling to right $=2$; falling to right $=3$; being unable to walk spontaneously and depression of consciousness $=4$ ) was evaluated by the same experimenter, who was blinded to the different treatments in the experiment, $24 \mathrm{~h}$ after reperfusion. 


\section{Infarct rate evaluation}

The size of infarction was evaluated at $24 \mathrm{~h}$ after MCAO using 2,3,5-tetrazolium chloride (TTC) staining. Mice were sacrificed with $10 \%$ chloral hydrate. Brains were removed and cut into $2 \mathrm{~mm}$-thick coronal sections and stained with $2 \%$ of TTC for $30 \mathrm{~min}$ at $37^{\circ} \mathrm{C}$. Then, we observed and taken pictures after the brains were fixed with $4 \%$ formaldehyde solution for $30 \mathrm{~min}$. The normal brain tissue is bright red and the infarcted brain tissue is pale. The infarct areas were measured using the Image-J software. The percentage of cerebral infarction area is calculated by the following formula: infarct rate $\%=$ ischemic area / total area $\times 100 \%$.

\section{Experiment grouping}

The rats were randomly divided into 9 groups with 8 rats in each group, namely the sham operation group, the model group, low-dose group (4 mg/kg) and high-dose group $(20 \mathrm{mg} / \mathrm{kg})$ of the compound 7i, low-dose group $(4 \mathrm{mg} / \mathrm{kg})$ and high-dose group (20 mg/kg) of the compound $7 \mathbf{j}$, low-dose group (4 mg/kg) and high-dose group (20 mg/kg) of lead compound and positive control butylphthalide dose group (20 mg/kg).

\section{Drugs supply and dosage.}

Compounds 7i, 7j and DX were synthesized as previously described. 3-n-Butylphthalide, a positive drug, was purchased from Sigma-Aldrich. In order to improve the water solubility of the compounds, we prepared the tested compounds in the form of the hydrochloride salt. After that, we formulated the compound into a solution of $2 \mathrm{mg} / \mathrm{mL}$ and $10 \mathrm{mg} / \mathrm{mL}$ with physiological saline. Finally, the administration was injected through the tail vein of the rat.

\section{Dosing regimen}

Three days before the model was made, the rats were given the tail vein once a day. The sham operation group and the model group were given the same amount of normal saline. Two hours after the third administration, the model of cerebral ischemia was started to make. The nylon silk thread was drawn out carefully from the lumen of the internal carotid artery and ligate the broken end to restore the blood flow of the internal carotid artery in the rat when ischemic for about $90 \mathrm{~min}$, so that the blood flow of the internal carotid artery of the rat can be reperfused. $24 \mathrm{~h}$ after the third administration, the compound group and the positive control group were administered once again through the tail vein. The sham operation group and the model group were injected with the same amount of solvent, the administration volume was $2 \mathrm{~mL} / \mathrm{kg}$ body weight, for a total of 4 administrations .

\section{Statistical analysis}

The SPSS 22.0 statistical software was used to statistically process the data, and the results are expressed as mean \pm SD. Analysis of variance was performed between groups, and Tukey HSD test was used for pairwise comparison. $\mathrm{P}<0.05$ is statistically significant. 
Supporting Information The HPLC, ${ }^{1} \mathrm{H}$ NMR and ${ }^{13} \mathrm{C}$ NMR spectrum of compounds (7a-r and $\left.\mathbf{6 h}, \mathbf{6 i}, \mathbf{6 1}\right)$.

Acknowledgements: This work was Supported by the Key Project of Natural Science Research in Universities of Anhui Province (No. KJ2020A0412), and the University-Enterprise Cooperative Project (No. 2020HZ062)

\section{Compliance with ethical standards}

Conflict of interest The authors declare no competing interests

\section{References}

[1] Wu J, Wang B, Li M, et al. Network pharmacology identification of mechanisms of cerebral ischemia injury amelioration by Baicalin and Geniposide. Eur. J. Pharmacol. 2019, 859: 172484. doi: 10.1016/j.ejphar.2019.172484.

[2] Feigin VL, Forouzanfar MH, Krishnamurthi R, et al. Murray, C. Global and regional burden of stroke during 1990-2010: findings from the Global Burden of Disease Study 2010. Lancet. 2014, 383(9913): 245-55. doi: 10.1016/S0140-6736(13)61953-4.

[3] Sommer; Clemens J. Ischemic stroke: experimental models and reality. Acta. Neuropathol. 2017, 133(2): 245-61. doi: 10.1007/s00401-017-1667-0.

[4] Roth GA, Forouzanfar MH, Moran AE, et al. Demographic and epidemiologic drivers of global cardiovascular mortality. N. Engl. J. Med. 2015, 372(14): 1333-41. doi: 10.1056/NEJMoa1406656.

[5] Deb P, Sharma S, Hassan KM. Pathophysiologic mechanisms of acute ischemic stroke: an overview with emphasis on therapeutic significance beyond thrombolysis. Pathophysiology. 2010, 17: 197-18. doi: 10.1016/j.pathophys.2009.12.001.

[6] Jung S, Gralla J, Fischer U, et al. Safety of endovascular treatment beyond the 6-h time window in 205 patients. Eur. J. Neurol. 2013, 20: 865-71. doi: 10.1111/ene.12069.

[7] Ovbiagele B, Kidwell CS, Starkman S, et al. Potential role of neuroprotective agents for the treatment of patients with acute ischemic stroke. Curr Treat Option Ne. 2003, 3(1): 9-20. doi: 10.1007/s11940-003-0027-7.

[8] Luo Y, Tang H, Li H, et al. Recent advances in the development of neuroprotective agents and therapeutic targets in the treatment of cerebral ischemia. Eur. J. Med. Chem, 2019, 162: 132-46. doi: 10.1016/j.ejmech.2018.11.014.

[9] Uzdensky AB. Photothrombotic Stroke as a Model of Ischemic Stroke. Transl. Stroke. Res. 2018, 9(5): 437-51. doi: $10.1007 / \mathrm{s} 12975-017-0593-8$.

[10] Tewes B, Frehland B, Schepmann D, et al. Conformationally constrained NR2B selective NMDA receptor antagonists derived from ifenprodil: Synthesis and biological evaluation of tetrahydro-3-benzazepine-1,7-diols. 
Bioorg. Med. Chem. 2010, 18(22): 8005-15. doi: 10.1016/j.bmc.2010.09.026.

[11] Nakase T, Yamazaki T, Ogura N, et al. The impact of inflammation on the pathogenesis and prognosis of ischemic stroke. J. Neurol. Sci. 2008, 271(1-2): 104-9. doi: 10.1016/j.jns.2008.03.020.

[12] Terao S, Yilmaz G, Stokes KY, et al. Blood cell-derived RANTES mediates cerebral microvascular dysfunction, inflammation and tissue injury after focal ischemia-reperfusion. Stoke. 2008, 39 (2): 2560-70. doi: 10.1161/strokeaha.107.513150.

[13] Pei J, You X, Fu Q. Inflammation in the pathogenesis of ischemic stroke. Front. Biosci (Landmark Ed). 2015, 20 : 772-83. doi: 10.2741/4336.

[14] Zeeli S, Weill T, Finkin-Groner E, et al. Synthesis and Biological Evaluation of Derivatives of Indoline as Highly Potent Antioxidant and Antiinflammatory Agents . J. Med. Chem. 2018, 61(9): 4004-19. doi: 10.1021/acs.jmedchem.8b00001.

[15] Doyle KP, Simon RP, Stenzel-Poore MP. Mechanisms of ischemic brain damage. Nueropharmacology. 2008, 55(3): 310-8. doi: 10.1016/j.neuropharm.2008.01.005.

[16] Benveniste H, Drejer J, Schousboe A, et al. Elevation of the extracellular concentrations of glutamate and aspartate in rat hippocampus during transient cerebral ischemia monitored by intracerebral microdialysis. J. Neurochem. 1984, 43(5): 1369-74. doi: 10.1111/j.1471-4159.1984.tb05396.x.

[17] Lai TW, Zhang S, Wang YT, Excitotoxicity and stroke: idenfying novel targets for neuroprotection. Prog. Neurobiol. 2014, 115: 157-88. doi: 10.1016/j.pneurobio.2013.11.006.

[18] Menniti F, Chenard B, Collins M, et al. CP-101,606, a potent neuroprotectant selective for forebrain neurons. Eur. J. Pharmacol. 1997, 331(2-3): 117-26. dou: 10.1016/S0014-2999(97)10092-9.

[19] Henter ID, De Sousa RT, Zarate CA. Glutamatergic Modulators in Depression. Harv. Rev. Psychiatry. 2018, 26(6): 307-19. doi: 10.1097/hrp.0000000000000183.

[20] Machado-Vieira R, Henter ID, Zarate CA. New targets for rapid antidepressant action. Prog. Neurobiol. 2017, 152: 21-37. doi: 10.1016/j.pneurobio.2015.12.001.

[21] Stroebel D, Buhl DL, Knafels JD, et al. A Novel Binding Mode Reveals Two Distinct Classes of NMDA Receptor GluN2B-selective Antagonists. Mol. Pharmacol. 2016, 89(5): 541-51. doi: 10.1124/mol.115.103036.

[22] Karakas E, Simorowski N, Furukawa H. Subunit arrangement and phenylethanolamine binding in GluN1/GluN2B NMDA receptors. Nature. 2011, 475(7355): 249-53. doi: 10.1038/nature10180.

[23] Rosa BM , Laura DL , Stefania F , et al. Targeting GluN2B-containing N-Methyl-D-aspartate receptors: design, synthesis, and binding affinity evaluation of novel 3-substituted indoles. Archiv. Der. Pharmazie. 2014, 347(8): 533-9. doi: 10.1002/ardp.201400061.

[24] Huang L, Wang J, Chen L, et al. Design, synthesis, and evaluation of NDGA analogues as potential anti-ischemic 
stroke agents. Eur. J. Med. Chem. 2018, 143: 1165-73. doi: 10.1016/j.ejmech.2017.09.028.

[25] Abdel-Salam OM, Baiuomy AR, Aribid MS, et al. The anti-inflammatory effects of the phosphodiesterase inhibitor pentoxifylline in the rat. Pharmacol. Res. 2003, 47(4): 331-40. doi: 10.1016/S1043-6618(03)00002-1.

[26] Temme L, Bechthold E, Schreiber JA, et al. Negative allosteric modulators of the GluN2B NMDA receptor with phenylethylamine structure embedded in ring-expanded and ring-contracted scaffolds. Eur. J. Med. Chem. 2020, 190: 112138. doi: 10.1016/j.ejmech.2020.112138.

[27] $\mathrm{Hu} \mathrm{H,} \mathrm{Li} \mathrm{Z,} \mathrm{Zhu} \mathrm{X,} \mathrm{et} \mathrm{al.} \mathrm{Gua} \mathrm{Lou} \mathrm{Gui} \mathrm{Zhi} \mathrm{decoction} \mathrm{suppresses} \mathrm{LPS-induced} \mathrm{activation} \mathrm{of} \mathrm{the} \mathrm{TLR4/NF- \kappa B}$ pathway in BV-2 murine microglial cells. Int. J. Mol. Med. 2013, 31(6): 1327-32. doi: 10.3892/ijmm.2013.1331.

[28] Durukan A, Tatlisumak T. Acute ischemic stroke: Overview of major experimental rodent models, pathophysiology, and therapy of focal cerebral ischemia. Pharmacol. Blochem. Be. 2007, 87(1):179-97. doi: 10.1016/j.pbb.2007.04.015.

[29] Ballabh P, Braun A, Nedergaard M. The blood - brain barrier: an overview Structure, reg $\mu$ lation, and clinical imPlications. Neurobiol. Dis, 2004, 16:1-13. doi: 10.1016/j.nbd.2003.12.016. 


\section{Supplementary Files}

This is a list of supplementary files associated with this preprint. Click to download.

- SupportingInformationfortheExperimentalStudies.pdf 